\title{
Factors Influencing Intentions in Hotel Booking Through Online Travel Intermediaries Applications
}

\author{
Keywords: \\ Trust; Perceived \\ ease of use; Price \\ and promotion; \\ Perceived \\ privacy/security; \\ Online reviews; \\ Online Booking \\ Intention.
}

Hany E.Mohamed

Faculty of Tourism and Hotel

Management, Helwan university

\section{ARTICLE INFO ABSTRACT}

\author{
Fatma Mohammed Abdelaal \\ Faculty of Tourism and Hotel \\ Management, Helwan University
}

\section{(JAAUTH) \\ Vol. 21, No. 3, (December 2021), PP.101-134.}

The tremendous development of technology and mobile devices at present is making a significant influence on the hotels sector, especially in online hotel reservations via new online travel intermediaries applications like (Booking and Trivago applications). These applications have a prominent role in the hotel sector. Little researches has been done about customers' perceptions of the use of booking broker applications. This study examined how some factors related to online travel intermediaries tend to influence the intentions of booking hotels. Therefore, customer questionnaires were distributed electronically due to the Coronavirus pandemic. The survey has six variables, i.e. "trust, ease of use, price and promotion, perceived privacy/security, online reviews, hotel booking intention." Kruskal-Wallis Tests, Mann-Whitney U test and confirmatory factor analysis (CFA) were used to analyze 204 customers who used online travel intermediaries before booking in five-star hotels in Cairo. The results indicate that the ease of use, price, promotion, perceived privacy/security, and online reviews of online travel intermediaries are directly related to the intentions of booking hotels online. Price, promotion and reviews are considered the key factors related to the use of travel intermediaries and because of the customers' passion for special prices as well as to explore the rating of their hotels before booking through this application. Thus, hotels can achieve a higher level of service quality to increase their rating through that application to attract more customers.

\section{Literature Review}

Earlier researches has focused on various factors that affect the intention of customers to reserve hotel lodging online. Despite some elements like time and sensitivity content (Wong and Law, 2005), payment method security (Wong and Law, 2005) and price (Law and Chung, 2003) were broadly explained. Thus, the present research employs a unique method to investigate the factors that affect the intentions of consumers to reserve hotel online, via participating in the recent reviews. Consequently, the current research aims at: (1) identifying factors affecting the 
intentions of consumers while reserving hotel accommodation through online travel intermediaries; (2) determining the variance in age categories, marital status and income of customers using online travel intermediaries to reserve hotel rooms via online applications. The results are expected to aid hotels administrators to recognize the techniques which boost the intentions of customers to book hotel rooms using online travel intermediaries.

The online booking system made use of diverse services, such as electronic reservation of hotel rooms, online booking methods in travel packages, flight tickets (Paré et al., 2014). Therefore, hotels all over the world rely progressively on influential online travel intermediaries, to enlarge their incomes (O'Connor, 2003; Tso and Law, 2005; Brewer et al., 2006). The mounting use of online travel intermediaries occurs because of diverse factors involving unpreserved and abstract nature hotel product (Tso and Law, 2005). The development of the internet, to a great extent, has influenced how hotels allocate and determine the prices of their products. In the mid-90s, online travel agencies like Expedia and Travelocity - known as online third-party sites - joined airline tickets and hotel accommodation from numerous suppliers immediately to customers (Carroll and Siguaw, 2003). Hence, online travel intermediaries are acknowledged to become extremely successful. One of the chief causes for the success of these electronic intermediaries lurks in their capability to offer inexpensive room prices than the ones provided by the hotel websites or their booking offices (Gazzoli et al., 2008).

As de Carlos et al. (2016) clarified, the internet and its applications aid customers by supplying data concerning the reservation of hotel rooms. Customers utilize it for looking up information about room rates. Recently, the internet is extensively employed as a universal channel in most hotels (Wang et al., 2016). Technology is gradually progressing, and, thus, customers progressively search for easy sources from which they can collect information, e.g., social media and other related online platforms intermediaries (Aeknarajindawat, 2019). In addition, because of cheap costs, the use of the internet has become swiftly prevalent among customers. It has become one of the foremost factors in human life (Saengchai and Jermsittiparsert, 2019). It can be utilized whenever needed and, for any purpose, such as to explore online reviews about a travel destination, hotel accommodation and rates (Masiero and Law, 2016). Via the internet, travelers can reach essential information previously and collect any extra information they require, according to their predictions before planning their holidays. Travelers can now smoothly detect fares and room prices and can even distinguish between hotels' rates (Aeknarajindawat, 2019).

Nowadays, several people utilize the internet to implement their work due to the remarkable development and expansion of using the World Wide Web all around the globe (Wong and Law, 2005). Nevertheless, research has clarified that hotel visitors rather choose to make comparisons between various hotel room prices from several travel websites than merely surfing the websites of hotels (Guillet and Law, 2010). Further, studies have conveyed that hotel guests rather seek to reserve their lodging via applications of online intermediaries to get cheaper prices and to save their travel expenditures (Jauhari et al., 2007). Thus, researches unveil that $32 \%$ of hotel income 
is produced via online booking applications (TravelClick, 2012). Not only do hotels utilize their websites as a chief channel of allocation, but also, they use online travel intermediaries as these third-parties are capable of reaching worldwide customers and enhance occupancy rates (Chen, 2014). In addition, online travel applications have been regarded as efficient channels of marketing to sell falter inventory and reach customers hotels may not be able to communicate with directly (Kotler, et al., 2010). In 2013, booking hotel rooms through online travel applications improved to become $14 \%$ and is still demanded by consumers (TravelClick, 2013).

Some other studies have to do with the characteristics of the website which are specifically linked to the kinds and signification of information through websites (Peng et al., 2013). Customers prefer to buy travel products on websites that provide adequate data, permitting them to assess the value of products (Dolnicar and Otter, 2003). Undoubtedly, people commonly escort two various stages to accomplish while looking for information: utilitarian and hedonic considerations (Dhar and Wertenbroch, 2000). These stages function independently as customers assess and create attitudes towards products, and, consequently, they permit customers to differentiate between other options based on utilitarian and hedonic characteristics (Mano and Oliver, 1993). Considering customers' behaviours in making decisions for travel products is now a crucial matter for both researchers and practitioners (Yavas and Babakus, 2003)

In 2010, sales growth was being accomplished through online booking applications. Online travel intermediaries' applications ought to be an extremely significant part of a hotel marketing policy because customers who reserve rooms through online applications tend to be more loyal and bring more income (Starkov and Safer, 2010). Additionally, a survey about hotel marketing revealed that the hotel industry in 2009 gave a huge value to online marketing and acknowledged the internet as the tool which greatly affects the cost of making revenues (Law et al., 2009). Accordingly, the internet has altered customer's behaviors by enabling customers to manage everything online (Mills and Law, 2004). Before making a booking, consumers surf many intermediaries on online travel websites. Consumers, then, contact their family and friends through facebook, conducting internet search via self-phones. (Starkov and Safer, 2010). Besides, from customers' perspective, online booking can be a beneficial element in several ways because it permits customers to compare between and collect the qualitative data they need, leads to speedy dealings, cost advantages and fast booking confirmations as well (Aeknarajindawat, 2019). Baltescu (2015) illustrated that most travelers search for numerous applications of hotels and resorts to check rates before making any booking. Further, booking through online applications enables consumers to communicate directly with hotels at any place and any time.

Various researches have determined elements that shape customers willingness to book hotel rooms online, highlighting creating value for customers (Francis and White, 2004), customer commitment and trust (Chen, 2006; Arnott et al., 2007; Kim and Ok, 2009; Kim et al., 2011; Ponte et al., 2015), perceived ease of use (Agag and El-Masry 2016), price and promotion (Emir et al., 2016), safety and privacy (Kim et al., 2014; Emir et al., 2016) and online reviews (Zhao et al., 2015; Emir et al., 2016). 
Nonetheless, slight attention has been paid to consolidating these factors into a whole model (Wang, 2008; Kim et al., 2012). Finally, a great deal of research evaluated the impact of individual features upon online booking behaviors for hospitality services, like demographics, knowledge of the product, online experiences and personality (Park et al., 2011; Amaro and Duarte, 2013). Among these, personal experiences (or familiarity) and knowledge mirroring individual dissimilarities have been focused on as chief causes of the process of making decisions online (Kim and Kim, 2004). Being familiar with the product prompts great confidence, leading customer's concern towards brands. Knowledge about hotel services affects the extent to which people play role in the information search process (Lehto et al., 2006; Lin and Chen, 2006; Park and Kim, 2010).

This research investigates the factors influencing customer perception of using online travel intermediaries' applications for online hotel booking intentions. This assists the hotel sector to identify weaknesses of applications and enhance them to achieve guest satisfaction and loyalty. In addition, these applications can increase the occupancy percentage all-round the year.

\section{Trust toward online intermediaries}

Trust is perceived as the person's believes that the online provider will accomplish its transactional obligations because those obligations are understood by the customer (Kim et al., 2008). Trust in applications plays a supreme role in tourism and hospitality as consumers may not book online if they do not trust the application (Kim et al., 2011). Alsajjan and Dennis (2010) concluded that trust affects customer attitude and willingness to occupy part in behaviour. Customers who trust online travel intermediaries' applications will have a positive intention towards them and may even book through these applications. Along the same lines, Ashraf et al. (2014); Amaro and Duarte (2015) found a noteworthy path from trust to customer attitude and booking intentions. Trust is particularly significant in booking online since customers may not book online if they do not trust the online travel intermediaries' applications (Kim et al., 2011).

From customers' perspective, trusting information supplied by the website plays a chief role (Muir and Moray, 1996; Liu and Arnett, 2000; Kim and Eom, 2002; Flavian et al., 2009). Accordingly, some researchers have highlighted the effect of customers trust and perceptions of the value generated by the information provided by the applications (Ranganathan and Ganapathy, 2002; Richard, 2005; Ganguly et al., 2010) on booking intentions. Trust positively affects the customer intention to use the online websites several times as stated by Poon (2008). Trusting information about a hotel website is extremely significant as hotel customers will normally surf the hotel website to get the hotel information. (Jylhä and Suvanto, 2015). According to Wong and Law (2005), information credibility is a substantial factor in determining the success of a hotel website inside online applications of intermediaries. All the details and information ought to be communicated to the customers clearly and concisely. If the hotel website can supply information accurately, customers will be content and faithful to the hotel (Emir et al., 2016). Scholars have shed light on five indicators to determine whether a website provides quality information. These indicators are: a 
variety of hotel web characteristics, connection to other sites, usefulness of content, visual appearance and information of rate (Wong and Law, 2005). Consequently, the following hypothesis can be suggested:

Trusting online intermediaries has a positive impact on intentions of booking hotels online.

\section{Perceived Ease of Use}

customer intentions are influenced by the ease of use (Chan et al., 2010). In addition, perceived ease of use has a noteworthy effect on customer's satisfaction and their intention to continue using an information system (Wu and Wang, 2005). Davis et al. (1989) stressed that ease of use positively influences the system's effectiveness. This positive correlation ship between ease of use and frequency of use is confirmed by (Bruner and Kumar, 2005). Emir et al. (2016) concluded that observed application interactivity affects booking intention via perceived utilitarian value and online trust. Thus, the following hypothesis can be proposed:

Perceived ease of use of online travel intermediaries positively affects intentions of booking hotels online.

\section{Price and Promotion}

Price is the only variable of the marketing mix that produces profits for a hotel, while all other elements of the mix are related to costs (O'Connor, 2003; Kotler, et al., 2006; Shoemaker, et al., 2007). Price discrimination is predominant in the hotels industry; it is a major tool utilized for prompting demand and amplifying profit opportunities for hotels (Kotler et al., 2010). Hotels, restaurants, and some other travel suppliers use various pricing techniques to obtain targeted revenues. For instance, hotels use a room rate strategy according to demand and customers' price sensitivity. Previous studies reveal that price dispersion and differentiation are common among tourism suppliers in the online environment (Clemons, et al., 2002; Toh, et al., 2011). Nevertheless, this can be challenging for hotels since room rates and product information can be easily retrieved by online customers. Therefore, hotel managers reported that "price wars" were the most threatening issue for management (Kimes, 2009). To remain competitive, hotels must constantly supervise market conditions and, accordingly, make room rate adjustments (Chen, 2014).

Hotels make use of diverse strategies to set prices for their offers. Hotel's managers usually choose various pricing methods according to a blend of numerous factors, namely: a hotel's cost structure, competitors' prices, and customer value perceptions of hotels services and products (Raab, et al., 2009). Shoemaker et al. (2007) proposed that pricing is a strong power in attracting attention and raising occupancies, and that it can also greatly affect customer faithfulness. In the meantime, sales promotions in hospitality e-commerce involve several formats such as price-reductions, coupon codes, premiums, and extra loyalty program points (Kotler et al., 2010; Christou 2011). Online sales promotions have attractive features and innovative ways to attract consumers to online travel applications (Sigala, 2013). For instance, the developing trend of enhancing online deals (accessible for a specific periods and with restricted inventory) has become widespread. These sales cause lack of product and raise 
consumers' impulsive purchases (Sigala, 2013). Generally, the effective promotion strategy determines hotel accommodation and amenities prices and, thus, the intention to book will increase (Emir et al., 2016). Price is the most important factor for users to purchase hotel accommodations (Law and Chung, 2003) and tourism products online (Law and Chung, 2003). Thus, the following hypothesis is proposed:

Concerning the reservation on online travel intermediaries, price and promotion have a positive effect on intentions to book a hotel online.

\section{Perceived privacy/security}

In several studies, privacy and security system including method of payment have been regarded as the chief causes of boosting online customers' trust to purchase any product (Arnott et al., 2007). Online travel intermediaries' applications are available online to everyone. Consequently, hotel customers are concerned with the security and privacy of the information they share on the application. For example, customers may be asked to reveal their personal information like name, gender, address, age, and credit card number to be able to make an online booking. That information may be liable to be violated by several risks such as online hacked and so on (Emir et al., 2016). Accordingly, the applications should be capable to provide great protection to keep customers' personal information safe. Tan (2015) mentioned that hotel website should provide a warrant that all the customers' personal information can only be accessed by official personnel and, thus, customers' privacy should be secured. Customers may use online booking when they trust the hotel booking website itself (Emir et al., 2016). Therefore, researchers presume the following hypothesis:

Perceived privacy/security has a positive influence on intentions to book hotel through online travel intermediaries.

\section{Online reviews}

Online reviews are referred to as eWOM (electronic word of mouth). Potential consumers can be influenced by the fact that people can post negative or positive analyses related to accommodation experiences. This results in increasing the credibility of customers. By using eWOM, hotels can get more enduring value than customers that are attained via traditional marketing channels (Bateson and Hoffman, 1999; Villanueva et al., 2008; Trusov et al., 2009). Online reviews are noteworthy due to their twofold role as they provide information about products and services and introduce recommendations to customers (Berbegal-Mirabent et al., 2016). Amaro and Duarte (2015) clarified that the foremost online travel agencies like Orbitz, Travelocity, Expedia and Priceline have their star rating systems and ratings generated by customers. For example, the well-known sites of Trip Advisor and Booking permit customer's ratings which mirror their service quality from customers' viewpoints shown on their websites (Aeknarajindawat, 2019)

Varkaris (2017) pinpointed how negative content displayed on social media platforms does not dismiss hotels but aims to make potential travellers quite uncertain about selecting a specific hotel. Nunthapirat, (2016) explicated how a mounting number of expected guests rely on reviews before making a booking. In cases of lodging and boarding in specific, it is obvious that customers trust the online reviews as one of the 
standards for decision making or booking. The review provided by Jain and Prabhu (2018) is regarded as significant and authentic information in booking decisions. Recently, customers freely express their individual experiences. Hotels are not the only source that provides customers with information. Hence, the present paper proposes the following hypothesis:

Online reviews have a positive influence on intentions to book hotel through online travel intermediaries.

\section{Online Booking Intention}

Online booking is considered one of the most desirable sections for customers. Electronic commerce based on the internet has changed noticeably when goods and services were enormously vended online (Bicen and Sadikoglu, 2016). Online booking system involves the fact that consumers need to pay in advance and, afterwards, experience the service in person. Online booking is the situation where physical distribution after booking does not exist; this entirely differs from online shopping for physical goods (Bicen and Sadikoglu, 2016; Elci, et al., 2017). Gössling (2017) clarified that online businesses swiftly increase annually. This has taken place because of the rising number of service providers that rely on using the web. This is in addition to the amplified number of multi-channel service providers that have multiple channels and who carry out the business online and offline. This policy which has multiple channels provides service providers with a competitive advantage over other suppliers who shed light merely on channels of online distribution. Further, customers think that booking hotel rooms online can be a beneficial element in many ways as it allows consumers to make comparisons and collect the qualitative data required. Online booking also permits rapidity in dealings, cost benefits and swift booking confirmations (Aeknarajindawat, 2019). Baltescu (2015) stated that the most customers surf various hotels websites or online travel agents for the sake of checking prices before decision-making. Additionally, online booking enables consumers to deal with hotels directly at any time and at any place. Therefore, Emir et al. (2016) concluded that the intention of booking hotel rooms online is understood as the possibility that the user of a hotel website or online travel intermediaries to purchase or book hotel accommodation via applications of travel intermediaries soon.

The dependent variable of the model is consumers' intentions of booking hotel rooms online.

\section{Research Framework and Hypotheses}

Therefore, five hypotheses and a proposed model (see Fig. 1) are presented below. 


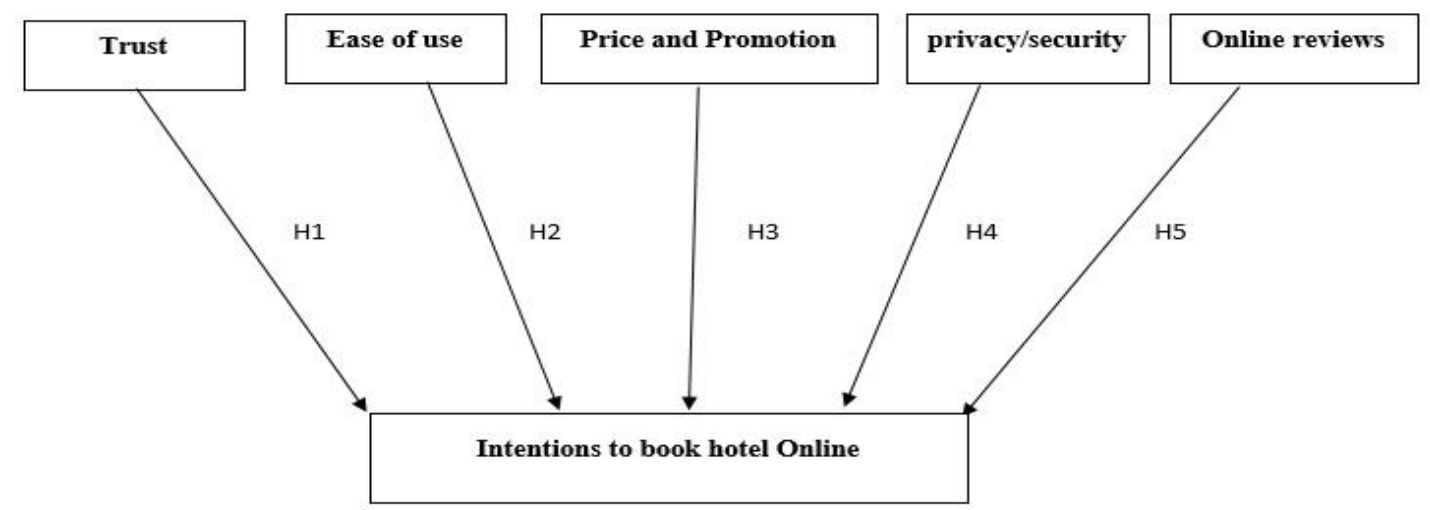

Fig.1. Proposed research model of the factors affecting customers' intentions in booking hotels through online travel intermediaries' applications

\section{Survey Instrument}

Despite the fact that using mobile applications to book hotels online through travel intermediaries (e.g., booking.com and trivago) plays an essential role in the hospitality industry (specifically in hotels) little research have approached this topic to investigate customers' perceptions concerning the factors affecting intentions to book online travel intermediaries. There is a tool that measures these factors by using a questionnaire that was distributed among customers to recognize customer perception toward using online hotel intermediaries' applications for determining customers' intentions towards hotel booking. The survey includes six constructs i.e., "trust; perceived ease of use; price and promotion; perceived privacy/security; online reviews; and intentions to book a hotel online.

This paper utilized an electronic survey as the data-aggregation tool, which was reviewed and redacted from former research (Bigné et al., 2010; Emir et al., 2016; Kim et al., 2017). The ultimate questionnaire items are presented in table (1) along with their sources. The questionnaire was adjusted through discourses with academic staff, hotels' managers, IT technicians, and several customers who use hotel booking mobile applications via online travel intermediaries. The questionnaire was carried out through a pilot study utilized to evaluate the language used in the questions, the question sequence, and length. The customers filled up the questionnaires to rate 22 items to answer the following question: to what extent do you agree or disagree with each statement? There are 5 points on the Likert scale: "strongly disagree," "disagree," "neutral," "agree" and "strongly agree". Each group of questions measured a specific aspect or point as follows:

- Trust construct as in questions 1-4

- Perceived ease of use as in questions 5-7

- Price and promotion as in questions 8-11

- Perceived privacy/security as in questions 12-15

- Online reviews as in questions 16-19

- Intentions to book a hotel via online travel intermediaries' applications as in questions 20-22 
The previous section enquired hotels customers about their perception concerning online travel intermediaries. The second section asked customers for demographic characteristics (i.e., gender, age, income, and education).

\section{Population, Sampling, and Procedures}

Questionnaire forms were distributed to a sample of 250 customers who stayed in five-star hotels and booked these hotels via online travel intermediaries (e.g., booking.com and trivago). The data was collected from these hotels with convenience sampling techniques, in which the researchers choose participants by judgmental sampling. Two hundred and eight questionnaire forms were valid for statistics use, representing 83.2 percent response rate.

There are five independent variables, namely: 1) trust, 2) perceived ease of use, 3) price and promotion, 4) perceived privacy / security, and 5) online reviews. The impact of such variables is generated on online hotel booking intention. The main objective of the present study is to determine the effects of the identified stimuli on online hotel booking intention.

\section{Table 1}

Construct measurement and sources

\begin{tabular}{|c|c|c|c|}
\hline Construct & Items & Measure & Source \\
\hline \multirow[t]{4}{*}{ Trust } & TRU1 & $\begin{array}{l}\text { I feel online booking intermediaries' } \\
\text { applications are reliable. }\end{array}$ & \multirow[t]{4}{*}{$\begin{array}{l}\text { Kim et al. } \\
\text { (2017) }\end{array}$} \\
\hline & TRU2 & $\begin{array}{l}\text { I think online booking intermediaries } \\
\text { applications will always be credible. }\end{array}$ & \\
\hline & TRU3 & $\begin{array}{l}\text { I trust the information provided by these } \\
\text { applications. }\end{array}$ & \\
\hline & TRU4 & $\begin{array}{l}\text { I think online travel intermediaries' } \\
\text { applications are honestly concerned about } \\
\text { me. }\end{array}$ & \\
\hline \multirow{3}{*}{$\begin{array}{l}\text { Perceived } \\
\text { Ease of Use } \\
\text { (PEU) }\end{array}$} & PEU1 & $\begin{array}{l}\text { I believe that learning to make use of hotel } \\
\text { online travel intermediaries would be easy. }\end{array}$ & \multirow{3}{*}{$\begin{array}{l}\text { Agag and } \\
\text { El-Masry } \\
\text { (2016) }\end{array}$} \\
\hline & PEU2 & $\begin{array}{l}\text { I believe that dealing with hotel online travel } \\
\text { intermediaries does not need a lot of mental } \\
\text { effort. }\end{array}$ & \\
\hline & PEU3 & $\begin{array}{l}\text { I believe that it is not difficult to use online } \\
\text { travel intermediaries to implement my travel } \\
\text { tasks. }\end{array}$ & \\
\hline \multirow[t]{4}{*}{$\begin{array}{l}\text { Price and } \\
\text { Promotion }\end{array}$} & P1 & $\begin{array}{l}\text { I think online travel intermediaries offers } \\
\text { reasonably priced the hotel }\end{array}$ & \multirow[t]{4}{*}{$\begin{array}{l}\text { Emir et al. } \\
(2016)\end{array}$} \\
\hline & P2 & $\begin{array}{l}\text { I always check hotel prices through travel } \\
\text { websites to be sure I get the best value. }\end{array}$ & \\
\hline & P3 & $\begin{array}{l}\text { I enjoy spending time comparing prices } \\
\text { through different websites. }\end{array}$ & \\
\hline & P4 & $\begin{array}{l}\text { I think online booking intermediaries present } \\
\text { special packages and promotions distinguish it }\end{array}$ & \\
\hline & & & Continued \\
\hline
\end{tabular}




\begin{tabular}{|c|c|c|c|}
\hline \multirow[t]{4}{*}{$\begin{array}{l}\text { Perceived } \\
\text { privacy/security }\end{array}$} & PSC1 & $\begin{array}{l}\text { I am worried about the privacy of my data } \\
\text { throughout any transaction. }\end{array}$ & \multirow{4}{*}{$\begin{array}{c}\text { Kim et al. } \\
\text { (2009); } \\
\text { Emir et al. } \\
\quad(2016)\end{array}$} \\
\hline & PSC2 & $\begin{array}{l}\text { The online travel intermediaries implements } \\
\text { security standards to protect me. }\end{array}$ & \\
\hline & PSC3 & $\begin{array}{l}\text { The thought of booking a room over the } \\
\text { application gives me an unwanted feeling of } \\
\text { anxiety. }\end{array}$ & \\
\hline & PSC4 & $\begin{array}{l}\text { I believe that booking a room over the } \\
\text { application makes me feel psychologically } \\
\text { uncomfortable. }\end{array}$ & \\
\hline \multirow[t]{4}{*}{ Online reviews } & OR1 & $\begin{array}{l}\text { I am more concerned with negative or } \\
\text { positive reviews when selecting the hotel }\end{array}$ & \multirow{4}{*}{$\begin{array}{c}\text { Zhao } \\
\text { et al. } \\
(2015) \text {; } \\
\text { Emir et al. } \\
\text { (2016) }\end{array}$} \\
\hline & OR2 & $\begin{array}{l}\text { I am more concerned with hotels that have } \\
\text { larger ratings on online applications. }\end{array}$ & \\
\hline & OR3 & $\begin{array}{l}\text { A larger volume of online reviews will } \\
\text { increase my booking intentions }\end{array}$ & \\
\hline & OR4 & $\begin{array}{l}\text { The latest reviews can mirror the most } \\
\text { updated performance of the hotel }\end{array}$ & \\
\hline \multirow[t]{3}{*}{$\begin{array}{l}\text { Intentions to } \\
\text { book hotel } \\
\text { Online }\end{array}$} & INT1 & $\begin{array}{l}\text { My intentions to book hotel rooms from } \\
\text { these online travel intermediaries' } \\
\text { applications are high. }\end{array}$ & \multirow{3}{*}{$\begin{array}{l}\text { Bigné et } \\
\text { al. (2010); } \\
\text { Kim et al. } \\
(2012) \text {; } \\
\text { Emir et al. } \\
(2016)\end{array}$} \\
\hline & INT2 & $\begin{array}{l}\text { I would put into consideration booking hotel } \\
\text { rooms from these applications if I were to } \\
\text { book rooms. }\end{array}$ & \\
\hline & INT3 & $\begin{array}{l}\text { In the future, I plan to book a hotel room } \\
\text { through online travel intermediaries. }\end{array}$ & \\
\hline
\end{tabular}

\section{Data Analysis}

The technique employed was represented in the Structural Equation Modeling (SEM) technique via using Analysis of Moment Structure (AMOS). AMOS is described as statistical software and it means analysis of moment structures. It is characterized by being an added SPSS module, and is used in specific for Structural Equation Modeling, path analysis, and confirmatory factor analysis. It is also acknowledged as an analysis of covariance or causal modeling software. Firstly, Confirmatory Factor Analysis (CFA) was employed to track the measurement model of mobile application satisfaction. Secondly, Cronbach's $\alpha$ and composite reliability (CR) were used as well to test the reliability of the constructs. Thirdly, the maximum likelihood was employed to measure the causal relationship amongst all variables. Fourthly, the Mann-Whitney U test and Kruskal-Wallis were used to investigate the distinctions between customers' gender, age, status and income.

\section{Respondents Profile}

Table (2) presents the customer profile who participates in the research. It is worth mentioning that 208 customers contributed to the study; $59.6 \%$ of whom were males and $40.4 \%$ were females. About $73.1 \%$ of participants' ages ranged from 21 to 40 years old. Those participants represented most of the customers, followed by $21.6 \%$ 
whose ages ranged from 41 to 60 years old, and $2.9 \%$ were less than 20 years old. Meanwhile, $2.4 \%$ of the sample ages exceeded 60 years old and $66.3 \%$ of all the samples were single. Moreover, $27.9 \%$ of them were married with children. On the other hand, $5.8 \%$ of them were married with no children. The income of most of the sample (49\%) ranged from 4001 to 6000 Egyptian pounds, followed by $30.3 \%$ of a sample whose income is more than 6000 Egyptian pounds. Finally, only $20.7 \%$ whose income ranged from 2000 to 4000 Egyptian pound.

Table 2

Customers' profiles $(\mathrm{N}=208)$

\begin{tabular}{|c|c|c|}
\hline Variables & Frequencies & Percentage \\
\hline \multicolumn{3}{|l|}{ Gender } \\
\hline Male & 124 & 59.6 \\
\hline Female & 84 & 40.4 \\
\hline \multicolumn{3}{|l|}{ Age } \\
\hline Less than 20 years old & 6 & 2.9 \\
\hline From 21 to 40 years old. & 152 & 73.1 \\
\hline From 41 to 60 years old. & 45 & 21.6 \\
\hline More than 60 years old & 5 & 2.4 \\
\hline \multicolumn{3}{|l|}{ Status } \\
\hline Single & 138 & 66.3 \\
\hline Married with children & 58 & 27.9 \\
\hline Married with no children & 12 & 5.8 \\
\hline \multicolumn{3}{|l|}{ Income } \\
\hline From L. E 2000 to L. E 4000 & 43 & 20.7 \\
\hline From L. E 4001 to L. E 6000 & 102 & 49.0 \\
\hline More than L. E 6000 & 63 & 30.3 \\
\hline
\end{tabular}

A descriptive analysis of the factors affecting customers' booking intention

SPSS version 23 was used to analyze the factors affecting hotels customers' booking intention through online travel intermediaries' applications (i.e., 22 items) descriptively. Twenty-two items were tested by their means and standard deviations. Table (3) shows that customers were mostly pleased with the hotels booking application through online travel intermediaries they utilized and the positive effects of hotels booking software options on the future booking processes, as follows: "I am more concerned with negative or positive reviews when selecting the hotel." ( $M=$ 4.37); "I am more concerned with hotels which have larger ratings on online applications." (4.29); "The latest reviews can mirror the most updated performance of the hotel" ( $\mathrm{M}=4.26)$; "I believe that it is not difficult to use online travel intermediaries to implement my travel tasks." $(M=4.18)$; "I always check hotel prices through online travel intermediaries' applications to be sure I get the best value." $(\mathrm{M}=4.18)$. However, most customers expressed their dissatisfaction with hotels booking intention through online travel intermediaries as follows: "I believe that booking room over the application makes me feel psychologically uncomfortable." $(\mathrm{M}=4.39)$; "I am worried about the privacy of my data throughout any transaction." $(\mathrm{M}=3.24)$; "I think online booking intermediaries' applications will always be 
credible." $(\mathrm{M}=3.40)$; "I trust the information provided by these applications." $(\mathrm{M}=$ 3.46).

\section{Table 3}

A descriptive analysis of the factors affecting customers' intentions in booking hotels through online applications of travel intermediaries

\begin{tabular}{|c|c|c|}
\hline 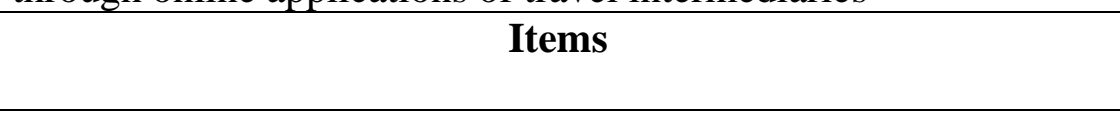 & Mean & $\begin{array}{c}\text { Std. } \\
\text { Deviation } \\
\end{array}$ \\
\hline \multicolumn{3}{|l|}{ Trust } \\
\hline $\begin{array}{l}\text { I feel online booking via travel intermediaries' applications are } \\
\text { reliable }\end{array}$ & 3.72 & .956 \\
\hline $\begin{array}{l}\text { I think online booking intermediaries' applications will always } \\
\text { be credible. }\end{array}$ & 3.40 & .948 \\
\hline I trust the information provided by these applications. & 3.46 & .889 \\
\hline $\begin{array}{l}\text { I think online travel intermediaries' applications are honestly } \\
\text { concerned about me. }\end{array}$ & 3.65 & .914 \\
\hline \multicolumn{3}{|l|}{$\begin{array}{l}\text { Perceived Ease of Use (PEU) } \\
\end{array}$} \\
\hline $\begin{array}{l}\text { I believe that learning to make use of hotel online travel } \\
\text { intermediaries would be easy. }\end{array}$ & 4.16 & .858 \\
\hline $\begin{array}{l}\text { I believe that dealing with hotel online travel intermediaries does } \\
\text { not need a lot of mental effort. }\end{array}$ & 3.87 & 1.006 \\
\hline $\begin{array}{l}\text { I believe that it is not difficult to use online travel intermediaries } \\
\text { to implement my travel tasks. }\end{array}$ & 4.18 & .801 \\
\hline \multicolumn{3}{|l|}{$\begin{array}{c}\text { Price and Promotion } \\
\end{array}$} \\
\hline $\begin{array}{l}\text { I think online booking intermediaries offer reasonable prices for } \\
\text { the hotel. }\end{array}$ & 3.70 & .903 \\
\hline $\begin{array}{l}\text { I always check hotel prices through online travel intermediaries' } \\
\text { applications to be sure I get the best value. }\end{array}$ & 4.18 & .797 \\
\hline I enjoy spending time comparing prices through different applications. & 3.91 & 1.015 \\
\hline $\begin{array}{l}\text { I think online booking intermediaries present special packages } \\
\text { and promotions distinguish it }\end{array}$ & 4.02 & .830 \\
\hline \multicolumn{3}{|l|}{ Perceived privacy/security } \\
\hline $\begin{array}{l}\text { I am worried about the privacy of my data throughout any } \\
\text { transaction. }\end{array}$ & 3.24 & 1.116 \\
\hline $\begin{array}{l}\text { The online travel intermediaries implements security standards to } \\
\text { protect me. }\end{array}$ & 4.06 & .871 \\
\hline $\begin{array}{l}\text { The thought of booking a room over the application gives me an } \\
\text { unwanted feeling of anxiety. }\end{array}$ & 4.15 & .809 \\
\hline $\begin{array}{l}\text { I believe that booking a room over the application makes me feel } \\
\text { psychologically uncomfortable. }\end{array}$ & 4.39 & .727 \\
\hline \multicolumn{3}{|l|}{ Online reviews } \\
\hline $\begin{array}{l}\text { I am more concerned with negative or positive reviews when } \\
\text { selecting the hotel }\end{array}$ & 4.37 & .661 \\
\hline $\begin{array}{l}\text { I am more concerned with hotels that have larger ratings on } \\
\text { online applications. }\end{array}$ & 4.29 & .797 \\
\hline & & Continued \\
\hline
\end{tabular}




\begin{tabular}{|l|c|c|}
\hline $\begin{array}{l}\text { A larger volume of online reviews will increase my booking } \\
\text { intentions. }\end{array}$ & 4.13 & .940 \\
\hline $\begin{array}{l}\text { The latest reviews can mirror the most updated performance of } \\
\text { the hotel }\end{array}$ & 4.26 & .730 \\
\hline \multicolumn{2}{|c|}{ Intentions to book hotel online } \\
\hline $\begin{array}{l}\text { My intentions to book hotel rooms from these online travel } \\
\text { intermediaries' applications are high. }\end{array}$ & 3.70 & .855 \\
\hline $\begin{array}{l}\text { I would put into consideration booking hotel rooms from these } \\
\text { applications if I were to book rooms. }\end{array}$ & 3.81 & .903 \\
\hline $\begin{array}{l}\text { In the future, I plan to book a hotel room through an online } \\
\text { intermediaries travel application. }\end{array}$ & 4.00 & .851 \\
\hline
\end{tabular}

\section{Variance Analysis}

\section{A statistical analysis of variance between genders in terms of application satisfaction}

The Mann-Whitney U test was used to determine if there is a significant difference between males $(\mathrm{N}=124)$ and females $(\mathrm{N}=84)$ in terms of hotels booking intention through online travel intermediaries' applications. Furthermore, the mean rank score is used to determine which group is higher. Table (4) shows this issue. For example, do females and males vary regarding online hotels booking intention?

As shown in Table (4), it can be noticed that the Mann-Whitney U test revealed no significant difference between males and females in terms of customers' perception of the 21 items regarding hotels booking intention through online travel intermediaries' applications. Female and male customers had identical perception in terms of hotels booking intentions through online travel intermediaries' applications. On the other hand, the test revealed statistically one significant difference between female and male customers in terms of online hotels booking intentions items. The results indicated that male customers had higher agreement and expectations towards "I believe that it is not difficult to use online travel intermediaries to implement my travel tasks." by achieving a higher mean rank score $(M=113.84)$ than female customers $(M=90.71)$.

\section{Table 4}

The effect of gender variation on the intentions in booking hotels through online applications of travel intermediaries

\begin{tabular}{|c|c|c|c|c|}
\hline Items & Gender & Mean Rank & Mann-Whitney U & Asymp. Sig. (2-tailed) \\
\hline \multirow{2}{*}{ TRU1 } & Male & 106.08 & \multirow[t]{2}{*}{5012.5} & \multirow[t]{2}{*}{.627} \\
\hline & Female & 102.17 & & \\
\hline \multirow[t]{2}{*}{ TRU2 } & Male & 107.32 & \multirow[t]{2}{*}{4858.5} & \multirow[t]{2}{*}{.380} \\
\hline & Female & 100.34 & & \\
\hline \multirow[t]{2}{*}{ TRU3 } & Male & 104.00 & \multirow[t]{2}{*}{5145.5} & \multirow[t]{2}{*}{.875} \\
\hline & Female & 105.24 & & \\
\hline \multirow[t]{2}{*}{ TRU4 } & Male & 102.05 & \multirow[t]{2}{*}{4904.0} & \multirow[t]{2}{*}{447} \\
\hline & Female & 108.12 & & \\
\hline PEU1 & Male & 108.07 & 4765.0 & .263 \\
\hline & & & & Continued \\
\hline
\end{tabular}




\begin{tabular}{|c|c|c|c|c|}
\hline & Female & 99.23 & & \\
\hline \multirow[t]{2}{*}{ PEU2 } & Male & 111.10 & \multirow[t]{2}{*}{4389.0} & \multirow[t]{2}{*}{.042} \\
\hline & Female & 94.75 & & \\
\hline \multirow[t]{2}{*}{ PEU3 } & Male & 113.84 & \multirow[t]{2}{*}{4050.0} & \multirow[t]{2}{*}{$.003 *$} \\
\hline & Female & 90.71 & & \\
\hline \multirow[t]{2}{*}{$\mathrm{P} 1$} & Male & 104.49 & \multirow[t]{2}{*}{5206.5} & \multirow[t]{2}{*}{.997} \\
\hline & Female & 104.52 & & \\
\hline \multirow[t]{2}{*}{ P2 } & Male & 104.84 & \multirow[t]{2}{*}{5166.0} & \multirow[t]{2}{*}{.914} \\
\hline & Female & 103.99 & & \\
\hline \multirow[t]{2}{*}{ P3 } & Male & 104.83 & \multirow[t]{2}{*}{5168.0} & \multirow[t]{2}{*}{.920} \\
\hline & Female & 104.02 & & \\
\hline \multirow[t]{2}{*}{$\mathrm{P} 4$} & Male & 99.08 & \multirow[t]{2}{*}{4535.5} & \multirow[t]{2}{*}{.094} \\
\hline & Female & 112.51 & & \\
\hline \multirow[t]{2}{*}{ PSC1 } & Male & 110.29 & \multirow[t]{2}{*}{4489.5} & \multirow[t]{2}{*}{.079} \\
\hline & Female & 95.95 & & \\
\hline \multirow[t]{2}{*}{ PSC2 } & Male & 103.76 & \multirow[t]{2}{*}{5116.5} & \multirow[t]{2}{*}{.818} \\
\hline & Female & 105.59 & & \\
\hline \multirow[t]{2}{*}{ PSC3 } & Male & 103.25 & \multirow[t]{2}{*}{5053.5} & \multirow[t]{2}{*}{.695} \\
\hline & Female & 106.34 & & \\
\hline \multirow[t]{2}{*}{ PSC4 } & Male & 107.03 & \multirow[t]{2}{*}{4894.0} & .412 \\
\hline & Female & 100.76 & & \\
\hline OR1 & Male & 106.45 & 4966.0 & .528 \\
\hline & Female & 101.63 & & \\
\hline OR2 & Male & 109.81 & 4550.0 & .092 \\
\hline & Female & 96.67 & & \\
\hline OR3 & Male & 105.13 & 5130.0 & .842 \\
\hline & Female & 103.57 & & \\
\hline OR4 & Male & 106.26 & 4990.0 & .578 \\
\hline & Female & 101.90 & & \\
\hline INT1 & Male & 102.13 & 4914.0 & .460 \\
\hline & Female & 108.00 & & \\
\hline INT2 & Male & 99.40 & 4575.0 & .116 \\
\hline & Female & 112.04 & & \\
\hline INT3 & Male & 102.27 & 4932.0 & .485 \\
\hline & Female & 107.79 & & \\
\hline
\end{tabular}

\section{P-value $<0.05=$ Significant}

The variance analysis among age categories regarding the intentions in booking applications:

The Kruskal-Wallis $\mathrm{H}$ test was used in this study to compare the customers' perceptions among the four age categories regarding hotels booking intentions through online travel intermediaries' applications. This is to determine if there is a significant difference between them. The following table presents this issue.

As shown in Table 5, it can be seen that the Kruskal-Wallis $\mathrm{H}$ test revealed ten significant differences among the age categories (four groups) regarding customers' intentions in hotels booking through online travel intermediary's applications in terms 
of "I trust the information provided by these applications"; customers' ages ranging from 20 to 40 years old achieved the highest mean rank score $(M=110.91)$. On the other hand, customers' ages above 60 years old achieved the lowest score by an average of (34.60). This means that customers' ages 20 to 40 had higher agreement and expectations towards this issue than other groups. Secondly, customers' ages ranging from 20 to 40 years old achieved the highest mean rank score $(M=108.80)$ regarding that "I believe that learning to make use of hotel online travel intermediaries would be easy." which means that this group had a higher perception to learn how to book online easily than other age groups. Thirdly, the results presented that customers' ages ranging from 20 to 40 years had a higher perception towards "I believe that dealing with hotel online travel intermediaries does not need a lot of mental effort." (111.14). Fourthly, customers' ages ranging from 20 to 40 years old achieved the highest mean rank score $(\mathrm{M}=108.97)$ towards "I believe that it is not difficult to use online travel intermediaries to implement my travel tasks.". Fifthly, customers who are less than 20 years old achieved the highest mean rank score $(\mathrm{M}=119.00)$ towards "I always check hotel prices through online travel intermediaries' applications to be sure I get the best value." which means that customers under 20 years of age are the most people who compare between different online booking intermediaries' applications to know the best prices for hotels. Sixthly, customers' ages which are less than 20 years old achieved the highest mean rank score $(\mathrm{M}=123.33)$ towards "I believe that booking room over the application makes me feel psychologically uncomfortable." This means that booking through these applications raises their fears and concerns. Seventhly, customers' ages that are less than 20 years old achieved the highest mean rank score $(M=168.00)$ towards "Larger volume of online reviews will increase my booking intentions." which means that this category is significantly affected by online reviews than others. Eighthly, customers who are less than 20 years old achieved the highest mean rank score $(\mathrm{M}=163.50)$ towards "The latest reviews can mirror the most updated performance of the hotel". This means that ages under 20 years old have an idea that the online travel intermediaries' ratings, which are characterized by their modernity, give an impression of the current performance to a great extent. Ninthly, customers' ages less than 20 years old achieved the highest mean rank score $(M=142.67)$ towards "My intentions to book hotel rooms from these online travel intermediaries' applications are high.". This means that young people under 20 years of age are most welcome to book through online travel intermediaries. Finally, customers' ages which are less than 20 years old achieved the highest mean rank score $(M=136.67)$ towards "I would put into consideration booking hotel rooms from these applications if I were to book rooms.". This may be because young people are affected by technology and its modernity, and, hence, online travel intermediaries are their first choice in the case of booking hotels. 
Table 5

The variance analysis among customer age categories regarding the intentions in booking hotels through online applications of travel intermediaries

\begin{tabular}{|c|c|c|c|c|}
\hline Items & age & Mean Rank & Chi-Square & Asymp. Sig. (2-tailed) \\
\hline \multirow{4}{*}{ TRU1 } & Less than 20 years & 121.00 & \multirow{4}{*}{10.275} & \multirow{4}{*}{.016} \\
\hline & $20-40$ & 105.13 & & \\
\hline & $41-60$ & 108.86 & & \\
\hline & More than 60 & 26.30 & & \\
\hline \multirow[t]{4}{*}{ TRU2 } & Less than 20 years & 101.00 & \multirow{4}{*}{6.870} & \multirow{4}{*}{.076} \\
\hline & $20-40$ & 106.86 & & \\
\hline & $41-60$ & 104.18 & & \\
\hline & More than 60 & 40.00 & & \\
\hline \multirow[t]{4}{*}{ TRU3 } & Less than 20 years & 67.00 & \multirow{4}{*}{13.516} & \multirow{4}{*}{$.004 *$} \\
\hline & $20-40$ & 110.91 & & \\
\hline & $41-60$ & 95.60 & & \\
\hline & More than 60 & 34.60 & & \\
\hline \multirow[t]{4}{*}{ TRU4 } & Less than 20 years & 102.33 & \multirow{4}{*}{5.989} & \multirow{4}{*}{.112} \\
\hline & $20-40$ & 108.59 & & \\
\hline & $41-60$ & 96.86 & & \\
\hline & More than 60 & 51.70 & & \\
\hline \multirow[t]{4}{*}{ PEU1 } & Less than 20 years & 82.50 & \multirow{4}{*}{17.983} & \multirow{4}{*}{$.000 *$} \\
\hline & $20-40$ & 108.80 & & \\
\hline & $41-60$ & 104.08 & & \\
\hline & More than 60 & 3.90 & & \\
\hline \multirow[t]{4}{*}{ PEU2 } & Less than 20 years & 23.33 & \multirow{4}{*}{19.729} & \multirow{4}{*}{$.000^{*}$} \\
\hline & $20-40$ & 111.14 & & \\
\hline & $41-60$ & 99.29 & & \\
\hline & More than 60 & 46.80 & & \\
\hline \multirow[t]{4}{*}{ PEU3 } & Less than 20 years & 42.17 & \multirow{4}{*}{22.889} & \multirow{4}{*}{$.000^{*}$} \\
\hline & $20-40$ & 108.97 & & \\
\hline & $41-60$ & 108.18 & & \\
\hline & More than 60 & 10.40 & & \\
\hline \multirow[t]{4}{*}{$\mathrm{P} 1$} & Less than 20 years & 53.00 & \multirow{4}{*}{10.204} & \multirow{4}{*}{.017} \\
\hline & $20-40$ & 108.39 & & \\
\hline & $41-60$ & 104.28 & & \\
\hline & More than 60 & 49.90 & & \\
\hline $\mathrm{P} 2$ & Less than 20 years & 119.00 & & \\
\hline & $20-40$ & 106.68 & 14.710 & $.002 *$ \\
\hline & $41-60$ & 105.56 & & \\
\hline & More than 60 & 11.20 & & \\
\hline P3 & Less than 20 years & 59.67 & & \\
\hline & $20-40$ & 106.78 & 9.522 & .023 \\
\hline & $41-60$ & 109.28 & & \\
\hline & More than 60 & 46.10 & & \\
\hline P4 & Less than 20 years & 127.00 & 7.497 & .058 \\
\hline & $20-40$ & 107.59 & & \\
\hline & $41-60$ & 97.62 & & \\
\hline & More than 60 & 45.40 & & \\
\hline & & & & Continued \\
\hline
\end{tabular}




\begin{tabular}{|c|c|c|c|c|}
\hline \multirow[t]{4}{*}{ PSC1 } & Less than 20 years & 86.00 & \multirow[t]{4}{*}{3.003} & \multirow[t]{4}{*}{.391} \\
\hline & $20-40$ & 105.96 & & \\
\hline & $41-60$ & 98.22 & & \\
\hline & More than 60 & 138.80 & & \\
\hline \multirow[t]{4}{*}{ PSC2 } & Less than 20 years & 117.00 & \multirow[t]{4}{*}{12.117} & \multirow[t]{4}{*}{.007} \\
\hline & $20-40$ & 105.51 & & \\
\hline & $41-60$ & 108.91 & & \\
\hline & More than 60 & 19.20 & & \\
\hline \multirow[t]{4}{*}{ PSC3 } & Less than 20 years & 120.50 & \multirow[t]{4}{*}{7.006} & \multirow[t]{4}{*}{.072} \\
\hline & $20-40$ & 102.23 & & \\
\hline & $41-60$ & 115.84 & & \\
\hline & More than 60 & 52.20 & & \\
\hline \multirow[t]{4}{*}{ PSC4 } & Less than 20 years & 123.33 & \multirow[t]{4}{*}{16.866} & \multirow[t]{4}{*}{$.001^{*}$} \\
\hline & $20-40$ & 104.00 & & \\
\hline & $41-60$ & 114.00 & & \\
\hline & More than 60 & 11.60 & & \\
\hline \multirow[t]{4}{*}{ OR1 } & Less than 20 years & 160.50 & \multirow[t]{4}{*}{11.356} & \multirow[t]{4}{*}{.010} \\
\hline & $20-40$ & 102.55 & & \\
\hline & $41-60$ & 109.24 & & \\
\hline & More than 60 & 54.00 & & \\
\hline \multirow[t]{4}{*}{ OR2 } & Less than 20 years & 157.00 & \multirow[t]{4}{*}{7.593} & \multirow[t]{4}{*}{.055} \\
\hline & $20-40$ & 102.39 & & \\
\hline & $41-60$ & 108.22 & & \\
\hline & More than 60 & 72.00 & & \\
\hline \multirow[t]{4}{*}{ OR3 } & Less than 20 years & 168.00 & \multirow[t]{4}{*}{15.048} & \multirow[t]{4}{*}{$.002 *$} \\
\hline & $20-40$ & 101.43 & & \\
\hline & $41-60$ & 112.93 & & \\
\hline & More than 60 & 45.80 & & \\
\hline \multirow[t]{4}{*}{ OR4 } & Less than 20 years & 163.50 & \multirow[t]{4}{*}{13.183} & \multirow[t]{4}{*}{$.004 *$} \\
\hline & $20-40$ & 107.16 & & \\
\hline & $41-60$ & 93.33 & & \\
\hline & More than 60 & 53.40 & & \\
\hline \multirow[t]{4}{*}{ INT1 } & Less than 20 years & 142.67 & 13.842 & $.003 *$ \\
\hline & $20-40$ & 103.88 & & \\
\hline & $41-60$ & 110.58 & & \\
\hline & More than 60 & 23.00 & & \\
\hline INT2 & Less than 20 years & 136.67 & 16.990 & $.001 *$ \\
\hline & $20-40$ & 107.88 & & \\
\hline & $41-60$ & 99.46 & & \\
\hline & More than 60 & 8.50 & & \\
\hline INT3 & Less than 20 years & 97.50 & 12.541 & .006 \\
\hline & $20-40$ & 108.74 & & \\
\hline & $41-60$ & 100.48 & & \\
\hline & More than 60 & 20.30 & & \\
\hline
\end{tabular}

P-value $<0.05=$ Significant 
The variance analysis among customer social status categories and income groups regarding the intentions in booking applications:

Table 6 shows that the Kruskal-Wallis $\mathrm{H}$ test revealed that there are no significant differences regarding customer social status except two significant differences among customer status (three groups) in terms of intentions in hotels booking through online travel intermediaries' applications. The results showed that single customers had a higher perception towards "I trust the information provided by these applications." (m $=110.67$ ). This means that single customers trust the information provided in the online travel intermediaries' applications more than others. Moreover, married customers with children achieved the highest mean rank score $(\mathrm{M}=110.11)$ towards "The online travel intermediaries implements security standards to protect me.". This means that these customers prefer to use online travel applications more than other customers because online travel intermediaries have standards to maintain customer confidentiality and these applications are safe. Meanwhile, as shown in Table 6, it can be noticed that the Kruskal-Wallis $\mathrm{H}$ test did not reveal any substantial differences between customers' income whether their income was from 2000 to 4000 L.E, from 4001 to 6000 L.E or more than 6000 L.E regarding online booking intention through online travel intermediaries' applications. This may be due to that hotel booking via online travel intermediaries is not mainly affected by customers' income. 
Table 6

The variance analysis among customer social status categories and income groups regarding the intentions of booking hotels through online applications of travel intermediaries:

\begin{tabular}{|c|c|c|c|c|c|c|c|c|}
\hline Items & Status & $\begin{array}{l}\text { Mean } \\
\text { Rank }\end{array}$ & Chi-Square & $\begin{array}{l}\text { Asymp. } \\
\text { Sig. (2- } \\
\text { tailed) }\end{array}$ & Income & Mean Rank & $\begin{array}{c}\text { Chi- } \\
\text { Square }\end{array}$ & $\begin{array}{l}\text { Asymp. } \\
\text { Sig. (2- } \\
\text { tailed) }\end{array}$ \\
\hline \multirow[t]{3}{*}{ TRU1 } & Single & 104.26 & \multirow[t]{3}{*}{.504} & \multirow{3}{*}{.777} & 2000 to 4000 & 107.58 & \multirow[t]{3}{*}{.329} & \multirow[t]{3}{*}{.848} \\
\hline & Married with children & 107.15 & & & 4001 to 6000 & 105.13 & & \\
\hline & Married with no children & 94.46 & & & More than 6000 & 101.38 & & \\
\hline \multirow[t]{3}{*}{ TRU2 } & Single & 102.86 & \multirow[t]{3}{*}{1.330} & \multirow[t]{3}{*}{.514} & 2000 to 4000 & 105.48 & \multirow[t]{3}{*}{.118} & \multirow[t]{3}{*}{.943} \\
\hline & Married with children & 110.76 & & & 4001 to 6000 & 105.34 & & \\
\hline & Married with no children & 93.08 & & & More than 6000 & 102.47 & & \\
\hline \multirow[t]{3}{*}{ TRU3 } & Single & 110.67 & \multirow[t]{3}{*}{13.893} & \multirow[t]{3}{*}{$.001 *$} & 2000 to 4000 & 95.67 & \multirow[t]{3}{*}{1.499} & \multirow[t]{3}{*}{.473} \\
\hline & Married with children & 101.47 & & & 4001 to 6000 & 105.42 & & \\
\hline & Married with no children & 48.17 & & & More than 6000 & 109.04 & & \\
\hline \multirow[t]{3}{*}{ TRU4 } & Single & 107.39 & \multirow[t]{3}{*}{5.778} & \multirow[t]{3}{*}{.056} & 2000 to 4000 & 102.37 & \multirow[t]{3}{*}{.077} & \multirow[t]{3}{*}{.962} \\
\hline & Married with children & 105.47 & & & 4001 to 6000 & 105.03 & & \\
\hline & Married with no children & 66.58 & & & More than 6000 & 105.09 & & \\
\hline \multirow[t]{3}{*}{ PEU1 } & Single & 107.17 & \multirow[t]{3}{*}{7.871} & \multirow[t]{3}{*}{.020} & 2000 to 4000 & 101.92 & \multirow[t]{3}{*}{.138} & \multirow[t]{3}{*}{.933} \\
\hline & Married with children & 107.26 & & & 4001 to 6000 & 105.69 & & \\
\hline & Married with no children & 60.50 & & & More than 6000 & 104.34 & & \\
\hline \multirow[t]{3}{*}{ PEU } & Single & 104.53 & \multirow[t]{3}{*}{7.502} & \multirow[t]{3}{*}{.023} & 2000 to 4000 & 113.79 & \multirow[t]{3}{*}{3.341} & \multirow[t]{3}{*}{.188} \\
\hline & Married with children & 112.93 & & & 4001 to 6000 & 106.89 & & \\
\hline & Married with no children & 63.42 & & & More than 6000 & 94.29 & & \\
\hline \multirow[t]{3}{*}{ PEU3 } & Single & 105.85 & \multirow[t]{3}{*}{7.783} & .020 & 2000 to 4000 & 106.83 & .826 & .662 \\
\hline & Married with children & 110.17 & & & 4001 to 6000 & 106.81 & & \\
\hline & Married with no children & 61.58 & & & More than 6000 & 99.17 & & \\
\hline $\mathrm{P} 1$ & Single & 109.51 & 6.360 & .042 & 2000 to 4000 & 107.28 & .443 & .801 \\
\hline & Married with children & 100.16 & & & 4001 to 6000 & 105.73 & & \\
\hline 1 & & & & & & & & ontinued \\
\hline
\end{tabular}




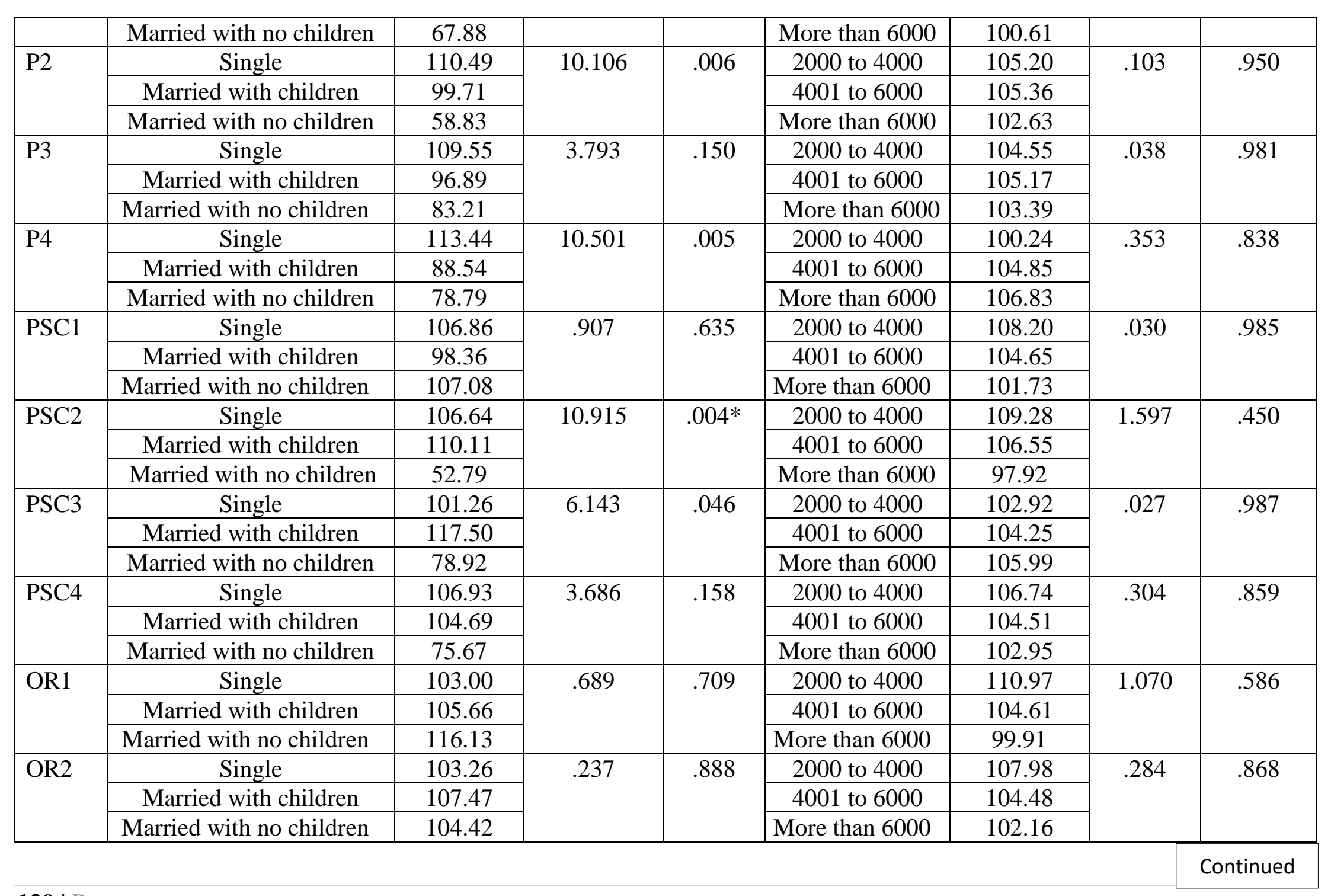

$\mathbf{1 2 0} \mid \mathrm{P}$ a g e 


\begin{tabular}{|c|c|c|c|c|c|c|c|c|}
\hline \multirow[t]{3}{*}{ OR3 } & Single & 104.80 & \multirow[t]{3}{*}{.014} & \multirow[t]{3}{*}{.993} & 2000 to 4000 & 115.91 & \multirow[t]{3}{*}{2.994} & \multirow[t]{3}{*}{.224} \\
\hline & Married with children & 104.00 & & & 4001 to 6000 & 104.34 & & \\
\hline & Married with no children & 103.42 & & & More than 6000 & 96.98 & & \\
\hline \multirow[t]{3}{*}{ OR4 } & Single & 110.67 & \multirow[t]{3}{*}{9.362} & \multirow[t]{3}{*}{.009} & 2000 to 4000 & 98.85 & \multirow[t]{3}{*}{.755} & \multirow[t]{3}{*}{.686} \\
\hline & Married with children & 86.08 & & & 4001 to 6000 & 104.48 & & \\
\hline & Married with no children & 122.54 & & & More than 6000 & 108.39 & & \\
\hline \multirow[t]{3}{*}{ INT1 } & Single & 104.59 & \multirow[t]{3}{*}{5.658} & \multirow[t]{3}{*}{.059} & 2000 to 4000 & 110.81 & \multirow[t]{3}{*}{1.087} & \multirow[t]{3}{*}{.581} \\
\hline & Married with children & 111.58 & & & 4001 to 6000 & 105.03 & & \\
\hline & Married with no children & 69.21 & & & More than 6000 & 99.33 & & \\
\hline \multirow[t]{3}{*}{ INT2 } & Single & 109.64 & \multirow[t]{3}{*}{4.464} & \multirow[t]{3}{*}{.107} & 2000 to 4000 & 105.37 & \multirow[t]{3}{*}{.116} & \multirow[t]{3}{*}{.944} \\
\hline & Married with children & 97.64 & & & 4001 to 6000 & 105.39 & & \\
\hline & Married with no children & 78.50 & & & More than 6000 & 102.46 & & \\
\hline \multirow[t]{3}{*}{ INT3 } & Single & 109.37 & \multirow[t]{3}{*}{4.061} & \multirow[t]{3}{*}{.131} & 2000 to 4000 & 106.52 & \multirow[t]{3}{*}{.539} & \multirow[t]{3}{*}{.764} \\
\hline & Married with children & 97.86 & & & 4001 to 6000 & 106.31 & & \\
\hline & Married with no children & 80.58 & & & More than 6000 & 100.18 & & \\
\hline
\end{tabular}

\section{P-value $<0.05=$ Significant}




\section{Analysis of Measurement Model}

\section{1) Confirmatory factor analysis (CFA)}

In this study, a confirmatory factor analysis (CFA) model fit test was done to test the reliability and validity of the six constructs (i.e., trust, perceived ease of use, price and promotion, perceived privacy/security, perceived ease of use, online reviews, and online booking intentions). Table 7 presents the results of the structural model with factor loading. Given this, not all factors loading is higher than 0.6 which means that the initial model was not a satisfactory fit. Hence, some modification indices are necessary before the testing to improve the model fit. More specifically, modification indices suggested remedies to four items from the research scale (i.e., P3; PSC1; OR1; OR4) have been deleted to achieve model fit indices).

Table 7

Factor loadings, validity analysis, and reliability test of the measurement model

\begin{tabular}{|c|c|c|c|c|c|}
\hline Code & Construct & $\begin{array}{c}\text { Factor } \\
\text { Loading }\end{array}$ & CR & $\mathbf{A}$ & AVE \\
\hline \multicolumn{6}{|c|}{ Independent Variables } \\
\hline \multicolumn{3}{|c|}{ 1- Trust } & .820 & .818 & .534 \\
\hline TRU1 & $\begin{array}{l}\text { I feel online booking intermediary's } \\
\text { applications are reliable. }\end{array}$ & .698 & & & \\
\hline TRU2 & $\begin{array}{l}\text { I think online booking intermediaries } \\
\text { applications will always be credible. }\end{array}$ & .761 & & & \\
\hline TRU3 & $\begin{array}{l}\text { I trust the information provided by these } \\
\text { applications. }\end{array}$ & .810 & & & \\
\hline TRU4 & $\begin{array}{l}\text { I think online travel intermediaries' } \\
\text { applications are honestly concerned about me. }\end{array}$ & .642 & & & \\
\hline \multicolumn{3}{|c|}{ 2- Perceived Ease of Use } & .801 & .800 & .575 \\
\hline PEU1 & $\begin{array}{l}\text { I believe that learning to make use of hotel } \\
\text { online travel intermediaries would be easy. }\end{array}$ & .796 & & & \\
\hline PEU2 & $\begin{array}{l}\text { I believe that dealing with hotel online travel } \\
\text { intermediaries does not need a lot of mental } \\
\text { effort. }\end{array}$ & .685 & & & \\
\hline PEU3 & $\begin{array}{l}\text { I believe that it is not difficult to use online travel } \\
\text { intermediaries to implement my travel tasks. }\end{array}$ & .788 & & & \\
\hline \multicolumn{3}{|c|}{ 3- Price and Promotion } & .773 & .770 & .533 \\
\hline P1 & $\begin{array}{l}\text { I think online booking intermediaries offers } \\
\text { reasonably priced the hotel }\end{array}$ & .748 & & & \\
\hline P2 & $\begin{array}{l}\text { I always check hotel prices through travel } \\
\text { websites to be sure I get the best value. }\end{array}$ & .650 & & & \\
\hline P3 & $\begin{array}{l}\text { I enjoy spending time comparing prices } \\
\text { through different websites. }\end{array}$ & - & & & \\
\hline P4 & $\begin{array}{l}\text { I think online booking intermediaries present } \\
\text { special packages and promotions distinguish it }\end{array}$ & .785 & & & \\
\hline \multicolumn{3}{|c|}{ 4- Perceived privacy/security } & .789 & .778 & .556 \\
\hline PSC1 & $\begin{array}{l}\text { I am worried about the privacy of my data } \\
\text { throughout any transaction. }\end{array}$ & - & & & \\
\hline
\end{tabular}




\begin{tabular}{|c|c|c|c|c|c|}
\hline PSC2 & $\begin{array}{l}\text { The online travel intermediaries implements } \\
\text { security standards to protect me. }\end{array}$ & .705 & & & \\
\hline PSC3 & $\begin{array}{l}\text { The thought of booking a room over the } \\
\text { application gives me an unwanted feeling of } \\
\text { anxiety. }\end{array}$ & .748 & & & \\
\hline PSC4 & $\begin{array}{l}\text { I believe that booking a room over the } \\
\text { application makes me feel psychologically } \\
\text { uncomfortable. }\end{array}$ & .782 & & & \\
\hline \multicolumn{3}{|c|}{ 5- Online reviews } & .752 & .750 & .602 \\
\hline OR1 & $\begin{array}{l}\text { I am more concerned with negative or } \\
\text { positive reviews when selecting the hotel }\end{array}$ & - & & & \\
\hline OR2 & $\begin{array}{l}\text { I am more concerned with hotels that have } \\
\text { larger ratings on online applications. }\end{array}$ & .806 & & & \\
\hline OR3 & $\begin{array}{l}\text { A larger volume of online reviews will } \\
\text { increase my booking intentions }\end{array}$ & .745 & & & \\
\hline OR4 & $\begin{array}{l}\text { The latest reviews can mirror the most } \\
\text { updated performance of the hotel }\end{array}$ & - & & & \\
\hline \multicolumn{6}{|c|}{ Dependent Variable } \\
\hline \multicolumn{2}{|c|}{ Online booking intentions } & & .785 & .774 & .550 \\
\hline INT1 & $\begin{array}{l}\text { My intentions to book hotel rooms from these } \\
\text { online travel intermediaries' applications are } \\
\text { high. }\end{array}$ & 679 & & & \\
\hline INT2 & $\begin{array}{l}\text { I would put into consideration booking hotel } \\
\text { rooms from these applications if I were to } \\
\text { book rooms. }\end{array}$ & .755 & & & \\
\hline INT3 & $\begin{array}{l}\text { In the future, I plan to book a hotel room } \\
\text { through travel websites. }\end{array}$ & .787 & & & \\
\hline
\end{tabular}

$\mathbf{C R}=$ Composite reliability; $\boldsymbol{\alpha}=$ Alpha reliability; $\mathbf{A V E}=$ average variance extracted

Results from the model estimate showed that total fit indicators for the good model fit for the acceptable threshold were achieved, with X2 $(51)=213.835 ; \mathrm{p}<.000,2 / \mathrm{df}=$ 1.07 lower than the acceptable value of 3. According to Nejatian et al. (2011), the model is well fitted to the evaluation criteria-based data, including GFI, CFI, TLI and RMSEA. To determine the model fit, at least three indices must be fitted well (Hair et al., 2010). GFI=0.830 (>.80 Hu and Bentler, 1999). IFI=0.905, TLI=0.920 and CFI= 0.940 indicating model Good Fit, within the upper threshold of $>.90$ (Tucker and Lewis 1973; Hu and Bentler, 1999). RMSEA = 0.069 (<0.08, Hair et al., 2010; Arbuckle, 2011). 


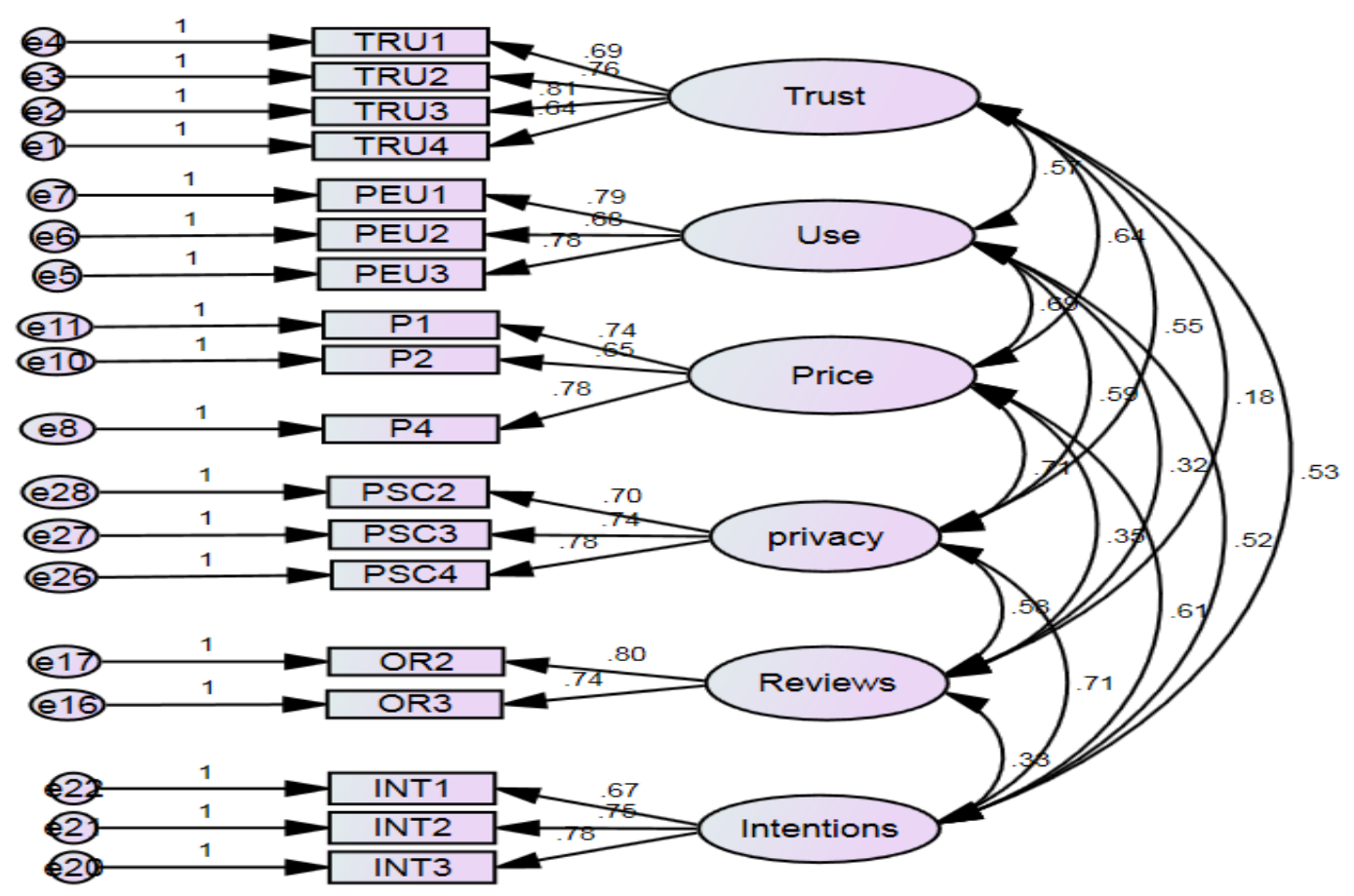

Figure.2. CFA of Latent Variable Construct of the Final Model

\section{Reliability, Convergent validity and Discriminant validity}

To test the reliability, table 7 as shown above presents the results of CFA which showed that the lowest value of CR and Cronbach's $\alpha$ for all the constructs was 0.75 , which exceeded the minimum acceptable value of 0.70 (Pallant, 2005), proving that data are reliable. Similarly, to test the convergent validity, CR and AVE were used. Correspondingly, to test the discriminant validity, MSV and ASV were used. Convergent Validity with the indices of CR and AVE exceeded the minimum acceptable level representing good convergent validity. On the other hand, The AVE of each study construct was larger than the squared correlation for the two constructs, showing good discriminant validity (see Table 8). This means that the measures are satisfactorily cohesive, and there are several common convergence points (Hair et al., 2010).

\section{Table 8}

Discriminant Validity for the Measurement Model

\begin{tabular}{|l|c|c|c|c|c|c|}
\hline \multicolumn{1}{|c|}{ Variables } & TRU & PEU & P & PSC & OR & INT \\
\hline Trust & $\mathbf{. 5 3 4}$ & & & & & \\
\hline Perceived Ease of Use & .327 & $\mathbf{. 5 7 5}$ & & & & \\
\hline Price and Promotion & .412 & .484 & $\mathbf{. 5 3 3}$ & & & \\
\hline Perceived privacy/security & .304 & .355 & .508 & $\mathbf{. 5 5 6}$ & & \\
\hline Online reviews & .032 & .106 & .123 & .337 & $\mathbf{. 6 0 2}$ & \\
\hline Online booking intentions & .283 & .279 & .378 & .512 & .109 & $\mathbf{. 5 5 0}$ \\
\hline
\end{tabular}

Note: The bold values along the diagonal line are the AVE values for the constructs, and the other values are the squared multiple correlations for each pair of constructs 


\section{Structural model and Hypotheses testing}

The hypothesized relationships

In view of the above, the hypothesized relationships were tested using standardized path coefficients (B) as shown in table 9. Overall, the structural model achieved acceptable fit $(\chi 2=141.219, \mathrm{df}=10, \mathrm{p}<0.01, \mathrm{CFI}=0.936, \mathrm{RMSEA}=0.036)$ (Hair et al., 2010). These estimates can be described as two factors (i.e., price and promotion and online reviews) are positively strong since its Absolute t-value $>3.29$, $\mathrm{p}<0.001$. The results showed that perceived ease of use, price and promotion, perceived privacy/security, and online reviews positively affected customers' online booking intention, supported $\mathrm{H} 2(\beta=\mathbf{2 0 0}$; $\mathrm{t}$-value = 2.655), H3 $(\beta=\mathbf{. 4 2 2}$; $\mathrm{t}$-value $=$ 5.040), H4 $(\beta=\mathbf{. 0 8 8}$; t-value $=\mathbf{2 . 0 5 9})$ and H5 $(\beta=\mathbf{. 0 3 2}$; t-value $=\mathbf{3 . 4 4 2})$, respectively. Meanwhile, trust did not have any effect on customers' intention to book online; this is contrary to the assumption that customers who trusted well in online website will raise their intention to book online (Reject $\mathrm{H} 1$ ).

Table 9

Standardized Parameter Estimates of the Structural Model

\begin{tabular}{|c|l|c|l|c|c|c|}
\hline H & \multicolumn{3}{|c|}{ Path } & $\begin{array}{c}\text { Beta } \\
\text { coefficients (B) }\end{array}$ & t-values & Results \\
\hline H1 & Trust & $\longrightarrow \begin{array}{l}\text { Online booking } \\
\text { intentions }\end{array}$ & $\mathbf{. 0 7 2}$ & $\mathbf{. 9 5 0}$ & Rejected \\
\hline H2 & $\begin{array}{l}\text { Perceived Ease } \\
\text { of Use }\end{array}$ & $\begin{array}{l}\text { Online booking } \\
\text { intentions }\end{array}$ & $\mathbf{. 2 0 0}$ & $\mathbf{2 . 6 5 5 * *}$ & Supported \\
\hline H3 & $\begin{array}{l}\text { Price and } \\
\text { Promotion }\end{array}$ & $\longrightarrow \begin{array}{l}\text { Online booking } \\
\text { intentions }\end{array}$ & $\mathbf{. 4 2 2}$ & $\mathbf{5 . 0 4 0 * * *}$ & Supported \\
\hline H4 & $\begin{array}{l}\text { Perceived } \\
\text { privacy/security }\end{array}$ & $\longrightarrow \begin{array}{l}\text { Online booking } \\
\text { intentions }\end{array}$ & $\mathbf{. 0 8 8}$ & $\mathbf{2 . 0 5 9} *$ & Supported \\
\hline H5 & Online reviews & $\longrightarrow \begin{array}{l}\text { Online booking } \\
\text { intentions }\end{array}$ & $\mathbf{. 0 3 2}$ & $\mathbf{3 . 4 4 2} * * *$ & Supported \\
\hline
\end{tabular}

*Absolute t-value $>1.96, \mathrm{p}<0.05 ; * *$ Absolute t-value $>2.58, \mathrm{p}<0.01 ; * * *$ Absolute t-value $>3.29, \mathrm{p}<0.001$.

\section{Discussion, Implications, and Conclusion}

This study explores the customers' perception regarding factors influencing hotel booking intentions via online hotel intermediaries' applications through examining the effect of trust, perceived ease of use, price and promotion, perceived privacy/security, online reviews on customers' intentions to book rooms online in Egyptian hotels. Furthermore, this paper shows and tests an adapted model that is composed of five hypotheses. The result of the study concluded that four hypotheses were supported and corresponded with analogous results in several studies as mentioned above.

Regarding trusting online travel intermediaries, the results of this research revealed that there is no significant relationship between trust and online booking intention. This is probably because most customers do not have enough experience to deal with these sites for their modernity, and, thus, those sites have not been trusted before, and it is possible to try to make a reservation through it without trust at the first time. For this reason, the $\mathrm{H} 1$ model is not supported. These findings differ from those of Alsajjan and Dennis (2010) who both found that trust lays an impact upon consumers' 
attitudes and intention to book rooms online. Consumers who trust online travel intermediaries' sites will have a positive attitude towards them and are more likely to rebook. Moreover, Kim et al. (2012) mentioned that when consumers trust online travel intermediaries, they tend to exert less effort to look for information about hotels and to compare between them. Lack of trust can cause consumers to evade online booking (Wu and Chang, 2005).

The findings of this paper presented considerable relationship of perceived ease of use regarding online intermediaries and intentions to book a hotel online. Therefore, it can be said that the ease of use of any application and site for booking hotels online raises customers' intentions to book through such sites or applications. Consequently, online travel intermediaries should design websites and applications that are easy to be used by their customers of different ages and this will affect their use and reservation of hotels. For this reason, the $\mathrm{H} 2$ model is supported. These results are like the study of Consult (2002) who indicated that perceived ease of use is referred to as the capability of respondents to try to use creative technology where they could assess its benefits effortlessly. It has been acknowledged as a significant element to change consumers' attitude and behavioral intentions and start the acceptance of technology usage amongst consumers (Cho and Sagynov, 2015).

With regards to price and promotion, the results of this research presented that there is a significant relationship between price, promotion and intentions to book a hotel online. This is probably due to that most of the travel intermediaries' applications rely on discounts to attract customers and make special price packages to motivate their customers to book through them, in addition to making promotional campaigns by offering several days with competitive prices through travel intermediaries. Moreover, hotels have recently relied on online travel intermediaries to sell their hotel rooms, especially after the Corona pandemic period, by reducing their prices through these applications, particularly after the occupancy rates have dropped due to the conditions of the Corona pandemic. Therefore, we find that the third hypothesis is supported. These findings agree with those of Law et al. (2007) who stated that online travel intermediaries are recognized by customers as offering a variety of choices at low prices. They are considered by many as the dominant choice when it comes to making travel arrangements as well as Pham and Ahammad (2017) who mentioned that the existence of online information allows customers to compare the benefits and prices of the product and services provided through the internet before making a purchase decision. Therefore, online businesses need to have a high perceived value, comparison between the benefits and sacrifices to obtain a product.

The study focuses on the significance of perceived privacy/security regarding online travel intermediaries. The results confirm the positive effect of perceived privacy/security online booking intentions, supporting H4. Perceived privacy/security is the most important issue for customer due to that personal and family data is significant to customers and it must be confidential, in addition to the privacy of bank accounts, especially since those applications accept payment by credit cards. Therefore, customers' intentions of online booking depend largely on maintaining the privacy and perceived security. These results are like the study of Tan (2015) when 
they indicated that online travel intermediaries' applications should confirm that all the customers' personal information can only be reached by official personnel and customers' privacy should be sustained. When customers trust hotel booking applications, they will have a greater intention to adopt online booking.

The research emphasizes significance of online reviews. The results confirm the positive effect of online reviews on online booking intentions, supporting H5. Online review is one of the most important factors that affect booking intentions, especially since customers can access comments easily on these applications. Hence, hotels are forced to improve their quality to increase their rating on online travel intermediaries' applications, because online travel intermediaries put rating with stars for each hotel. The customer can review all the comments for the desired hotel and choose the ideal deal, and thus the research summarized those online reviews are one of the most important influences that affect the intention to book. Moreover, due to the conditions of the Covid-19 pandemic these applications provide a special evaluation for hotels that apply precautionary measures. These results are consistent with the study of Jeong and Jeon (2008) who stated that hotel customers provide their ratings and reviews relying on their individual experience, contentment, and reconsider their intention. To a great extent, this affects how potential consumers understand the suggested product, and, thus, influences decision-making. Similarly, Hua (2016) added that the suggestions about products or services can be negative or positive. In addition, online comments offer pleasant and trustworthy and new data. Star ratings of hotels are defined relying on the value of the hotel. It is one of the guidelines that hotel customers can use to select the chosen hotel and book the room.

Hence, it may be deduced that the study in hand attempts to confirm that if hotels ignore using online travel intermediaries, this may weaken hotels marketing and lead to losing more customers who use these applications. Hence, this causes failure in creating revenues. Designing online travel intermediaries' applications and sites characterized by speed, efficiency, privacy, and ease of use is considered a good investment and generates more business for hotels which ultimately promotes their growth. On the other hand, online travel intermediaries help in making appropriate rating after visiting hotels; this rating is left in these applications as a benefit to other customers because the hotels can enhance their service quality to improve their ratings via customers' ratings on these applications. Moreover, designing trustworthy online travel intermediaries' applications - which display photos of hotels in addition to presenting comments for customers who have visited the hotel before - can raise new customers' expectations and intentions in booking and in taking decisions. Many managers understand the importance of online travel intermediaries, and, consequently, hotel managers may benefit from knowing the most factors influencing online booking intentions. In addition, putting new marketing strategies depends on online travel intermediaries to raise their occupancy percentage and make a competitive advantage. Furthermore, hotel managers may employ the results of this study to gain new approaches which could be useful during implementing marketing strategies. These strategies depend on online booking applications and effectively increase customers' intentions to book continuously through these applications. 


\section{Limitation and Suggestions for Future Research}

This study involves diverse limitations. First, this study utilized only onlinequestionnaires which were distributed to customers because of the Covid-19 pandemic. Further study could also use qualitative method to do more interviews with restaurants' customers to identify the customers' expectations and perception of online food delivery applications (FDAs) and how they make decisions at restaurants in Egypt during the covid-19 pandemic period. Second, the existing study investigated the effect of 19 independent variables on one dependent variable, namely customer's intentions to book hotels online. Moderator variables should be added to find out the relationship between the factors of independent variables which influence the purchasing decisions (FDAs) to give a clearer understanding of such relationship.

\section{References}

- Aeknarajindawat., N. (2019). The Factors Influencing Tourists' Online Hotel Reservations in Thailand: An Empirical Study, International Journal of Innovation, Creativity and Change, 10(1), 121-136.

- Agag, G., and El-Masry, A. A. (2016). Understanding the determinants of hotel booking intentions and moderating role of habit. International Journal of Hospitality Management, 54, 52-67.

- Alsajjan, B., and Dennis, C. (2010). Internet banking acceptance model: Crossmarket examination. Journal of business research, 63(9-10), 957-963.

- Amaro, S., and Duarte, P. (2013). Online travel purchasing: A literature review. Journal of Travel and Tourism Marketing, 30(8), 755-785.

- Amaro, S., and Duarte, P. (2015). An integrative model of consumers' intentions to purchase travel online. Tourism management, 46, 64-79.

- Arbuckle, J. L. (2011). IBM SPSS Amos 20 user's guide. Amos Development Corporation, SPSS Inc.

- Arnott, D. C., Wilson, D., Mukherjee, A., and Nath, P. (2007). Role of electronic trust in online retailing. European Journal of Marketing, 41 (9/10),1173-1202.

- Ashraf, A. R., Thongpapanl, N., and Auh, S. (2014). The application of the technology acceptance model under different cultural contexts: The case of online shopping adoption. Journal of International Marketing, 22(3), 68-93.

- available from https://www.mdpi.com/2071-1050/9/12/2262, accessed at $10 / 10 / 2020$

- Baltescu, C. A. (2015). The online assessment of tourism services. The hotel market from Brasov County. Bulletin of the Transilvania University of Brasov. Economic Sciences. Series V, 8(2), 142.

- Bateson, E., and Hoffman, K. D. (1999). Managing Service Marketing. Dryden Press.

- Berbegal-Mirabent, J., Mas-Machuca, M., and Marimon, F. (2016). Antecedents of online purchasing behaviour in the tourism sector. Industrial Management and Data Systems, 116(1), 87-102.

- Bicen, H., and Sadikoglu, S. (2016). Determination of the opinions of students on Tourism impact using Mobile Applications. Procedia Economics and Finance, 39, 270-274. 
- Bigné, E., Sanz, S., Ruiz, C., and Aldás, J. (2010). Why some internet users don't buy air tickets online. In Information and communication technologies in tourism 2010 (pp. 209-221). Springer, Vienna.

- Brewer, P., Feinstein, A. H., and Bai, B. (2006). Electronic Channels of Distributions: Challenges and Solutions for Hotel Operators. Hospitality Review, 24(2), 68-77.

- Bruner, G. C., and Kumar, A. (2005). Applying TAM to consumer usage of handheld Internet devices. Journal of Business Research, 58(5), 553-558.

- Carroll, B., and Siguaw, J. (2003). The evolution of electronic distribution: Effects on hotels and intermediaries. Cornell Hotel and Restaurant Administration Quarterly, 44(4), 38-50.

- Chan, F. K., Thong, J. Y., Venkatesh, V., Brown, S. A., Hu, P. J., and Tam, K. Y. (2010). Modeling citizen satisfaction with mandatory adoption of an e-government technology. Journal of the association for information systems, 11(10), 519-549.

- Chen, C. (2006). Identifying significant factors influencing consumer trust in an online travel site. Information Technology and Tourism, 8(3-4), 197-214.

- Chen, S. (2014). Consumer behavior of hotel deal bookings through online travel intermediaries (Doctoral dissertation), Faculty of Texas, Tech University.

- Cho, Y. C., and Sagynov, E. (2015). Exploring factors that affect usefulness, ease of use, trust, and purchase intention in the online environment. International Journal of Management and Information Systems (IJMIS), 19(1), 21-36.

- Christou, E. (2011). Exploring online sales promotions in the hospitality industry. Journal of Hospitality Marketing and Management, 20(7), 814-829.

- Clemons, E. K., Hann, I. H., and Hitt, L. M. (2002). Price dispersion and differentiation in online travel: An empirical investigation. Management science, 48(4), 534-549.

- Consult, A. N. (2002). China online banking study. Chinese Business Review. Available: http://estore.chinaonline.com/chinonlbanstu.html.

- Davis, F. D., Bagozzi, R. P., and Warshaw, P. R. (1989). User acceptance of computer technology: A comparison of two theoretical models. Management science, 35(8), 982-1003

- de Carlos, P., Araújo, N., and Fraiz, J. A. (2016). The new intermediaries of tourist distribution: Analysis of online accommodation booking sites. The International Journal of Management Science and Information Technology (IJMSIT), (19), 3958.

- Dhar, R., and Wertenbroch, K. (2000). Consumer choice between hedonic and utilitarian goods. Journal of marketing research, 37(1), 60-71.

- Dolnicar, S., and Otter, T. (2003). Which hotel attributes matter? A review of previous and a framework for future research, 176-188.

- Elci, A., Abubakar, A. M., Ilkan, M., Kolawole, E. K., and Lasisi, T. T. (2017). The impact of Travel 2.0 on travelers booking and reservation behaviors. Business Perspectives and Research, 5(2), 124-136.

- Emir, A., Halim, H., Hedre, A., Abdullah, D., Azmi, A., and Kamal, S. B. M. (2016). Factors influencing online hotel booking intention: A conceptual framework from stimulus-organism-response perspective. International Academic Research Journal of Business and Technology, 2(2), 129-134. 
- Flavian, C., Gurrea, R., and Orus, C. (2009). Web design: a key factor for the website success. Journal of Systems and Information Technology, 11(2),168-184.

- Francis, J. E., and White, L. (2004). Value across fulfillment-product categories of Internet shopping. Managing Service Quality: An International Journal, 14 (2/3), 226-234.

- Ganguly, B., Dash, S. B., Cyr, D., and Head, M. (2010). The effects of website design on purchase intention in online shopping: the mediating role of trust and the moderating role of culture. International Journal of Electronic Business, 8(4-5), 302-330.

- Gazzoli, G., Kim, W. G., and Palakurthi, R. (2008). Online distribution strategies and competition: are the global hotel companies getting it right? International Journal of Contemporary Hospitality Management, Vol. 20 No. 4, pp. 375-387.

- Gössling, S. (2017). Tourism, information technologies and sustainability: an exploratory review. Journal of Sustainable Tourism, 25(7), 1024-1041.

- Guillet, B. D., and Law, R. (2010). Analyzing hotel star ratings on third-party distribution websites. International Journal of Contemporary Hospitality Management. Retrieved from: http://doi.org/10.1108/09596111011063098

- Hair, J., Black, W., Babin, B., andAnderson, R. (2010). Multivariate Data Analysis.7th ed., Prentice-Hall, Inc, Upper Saddle River, NJ, USA.

- Hu, L. T., and Bentler, P. M. (1999). Cutoff criteria for fit indexes in covariance structure analysis: Conventional criteria versus new alternatives. Structural equation modeling: a multidisciplinary journal, 6(1), 1-55.

- Hua, N. (2016). E-commerce performance in hospitality and tourism. International Journal of Contemporary Hospitality Management, 28(9), 2052-2079.

- Jain, S. and Prabhu, A. (2018). Study of the Determinants that Influence Online Hotel Bookings, Journal of Research in Commerce and Management, 7(2)

- Jauhari, V., Dabas, S., and Manaktola, K. (2007). Managing reservations through online distribution channels. International Journal of Contemporary Hospitality Management, 19(5), 388-396.

- Jeong, M., and Mindy Jeon, M. (2008). Customer reviews of hotel experiences through consumer generated media (CGM). Journal of Hospitality and Leisure Marketing, 17(1-2), 121-138.

- Jylhä, T., and Suvanto, M. E. (2015). Impacts of poor quality of information in the facility management field. Facilities, 33(5/6), 302-319.

- Kim, D. J., Ferrin, D. L., and Rao, H. R. (2008). A trust-based consumer decisionmaking model in electronic commerce: The role of trust, perceived risk, and their antecedents. Decision support systems, 44(2), 544-564.

- Kim, E. B., and Eom, S. B. (2002). Designing effective cyber store user interface. Industrial Management and Data Systems.

- Kim, H. W., Xu, Y., and Gupta, S. (2012). Which is more important in Internet shopping, perceived price or trust?. Electronic commerce research and applications, 11(3), 241-252.

- Kim, L. H., Qu, H., and Kim, D. J. (2009). A study of perceived risk and risk reduction of purchasing air-tickets online. Journal of Travel and Tourism Marketing, 26(3), 203-224. 
- Kim, M. J., Chung, N., and Lee, C. K. (2011). The effect of perceived trust on electronic commerce: Shopping online for tourism products and services in South Korea. Tourism Management, 32(2), 256-265.

- Kim, S. Y., Kim, J. U., and Park, S. C. (2017). The effects of perceived value, website trust and hotel trust on online hotel booking intention. Sustainability, 9(12), 2262.

- Kim, W. G., and Kim, D. J. (2004). Factors affecting online hotel reservation intention between online and non-online customers. International Journal of Hospitality Management, 23(4), 381-395.

- Kim, W., and Ok, C. (2009). The effects of relational benefits on customers' perception of favorable inequity, affective commitment, and repurchase intention in full-service restaurants. Journal of Hospitality and Tourism Research, 33(2), 227-244.

- Kimes, S. E. (2009). Hotel revenue management in an economic downturn: Results from an international study.

- Kotler P.; Bowen J. and Markens (2006). Marketing for Tourism and Hospitality. 4th edition, Pearson Education International: New Jersey.

- Kotler, P., Bowen, J. T., and Makens, J. C. (2010). Marketing for hospitality and tourism. Boston: Prentice Hall.

- Law, R., and Chung, T. (2003). Website performance: Hong Kong hotels. Hospitality Review, 21(1), 4.

- Law, R., Chan, I., and Goh, C. (2007). Where to find the lowest hotel room rates on the internet? The case of Hong Kong. International Journal of Contemporary Hospitality Management, 19(6/7), 495-506.

- Law, R., Leung, R., \& Buhalis, D. (2009). Information technology applications in hospitality and tourism: a review of publications from 2005 to 2007. Journal of travel \& tourism marketing, 26(5-6), 599-623.

- Lin, L. Y., and Chen, C. S. (2006). The influence of the country-of-origin image, product knowledge and product involvement on consumer purchase decisions: an empirical study of insurance and catering services in Taiwan. Journal of consumer Marketing, 23(5): 248-265.

- Liu, C., and Arnett, K. P. (2000). Exploring the factors associated with Web site success in the context of electronic commerce. Information and management, 38(1), 23-33.

- Mano, H., and Oliver, R. L. (1993). Assessing the dimensionality and structure of the consumption experience: evaluation, feeling, and satisfaction. Journal of Consumer research, 20(3), 451-466.

- Masiero, L., and Law, R. (2016). Comparing reservation channels for hotel rooms: A behavioral perspective. Journal of travel and tourism marketing, 33(1), 1-13.

- Mills, J., and Law, R. (2004). Handbook of consumer behaviour, tourism and the Internet, Harworth.

- Muir, B. M., and Moray, N. (1996). Trust in automation. Part II. Experimental studies of trust and human intervention in a process control simulation. Ergonomics, 39(3), 429-460. 
- Nunthapirat, D. (2016). Dealing with Customers' Online Reviews: what Approach Hotel Managers Need to Address. Annual International Conference On Tourism and Hospitality Research, 57-62. Retrieved from:10.5176/2251-3426_THoR16.14.

- O'connor, P. (2003). On-line pricing: An analysis of hotel-company practices. Cornell Hotel and Restaurant Administration Quarterly, 44(1), 88-96.

- O'connor, P. (2002). An empirical analysis of hotel chain online pricing strategies. Information Technology and Tourism, 5(2), 65-72.

- Paré, G., Trudel, M. C., and Forget, P. (2014). Adoption, use, and impact of ebooking in private medical practices: mixed-methods evaluation of a two-year showcase project in Canada. JMIR medical informatics, 2(2), e24. Retrieved from: 10.2196/medinform.3669.

- Park, S., and Kim, D. Y. (2010). A comparison of different approaches to segment information search behaviour of spring break travellers in the USA: experience, knowledge, involvement and specialisation concept. International Journal of Tourism Research, 12(1), 49-64.

- Park, S., Wang, D., and Fesenmaier, D. (2011). Assessing structure in American online purchase of travel products. Anatolia, 22(3), 401-417.

- Peng, H., Xu, X., and Chen, W. (2013). Tourist behaviors in online booking: A new research agenda. Communications in information science and management engineering, 3(6), 280-285

- Pham, T. S. H., and Ahammad, M. F. (2017). Antecedents and consequences of online customer satisfaction: A holistic process perspective. Technological Forecasting and Social Change, 124, 332-342.

- Ponte, E. B., Carvajal-Trujillo, E., and Escobar-Rodríguez, T. (2015). Influence of trust and perceived value on the intention to purchase travel online: Integrating the effects of assurance on trust antecedents. Tourism Management, 47, 286-302.

- Poon, W. C. (2008). Users' adoption of e-banking services: the Malaysian perspective. Journal of business and industrial marketing, 23(1), pp.59-69.

- Raab, C., Mayer, K., Kim, Y. S., and Shoemaker, S. (2009). Price-sensitivity measurement: a tool for restaurant menu pricing. Journal of Hospitality and Tourism Research, 33(1), 93-105.

- Ranganathan, C., and Ganapathy, S. (2002). Key dimensions of business-toconsumer web sites. Information and management, 39(6), 457-465.

- Richard, M. O. (2005). Modeling the impact of internet atmospherics on surfer behavior. Journal of business research, 58(12), 1632-1642.

- Saengchai, S. and Jermsittiparsert, K. (2019). Improving Sustainability Performance through Internet of Things Capability in Thailand: Mediating Role of IOT Enabled Supply Chain Integration. International Journal of Supply Chain Management, 8(5), 572-584.

- Shoemaker, S., Lewis, R. C., Yesawich, P. C., and Chambers, R. E. (2007). Marketing leadership in hospitality and tourism: Strategies and tactics for competitive advantage. Upper Saddle River, NJ: Pearson Prentice Hall.

- Sigala, M. (2013). A framework for designing and implementing effective online coupons in tourism and hospitality. Journal of Vacation Marketing, 19(2), 165180 . 
- Starkov, M., and Safer, M. M. (2010). Hotelier's 2010 Top Ten Internet Marketing Resolutions. Hospitality eBusiness Strategies (HeBS).http://www.hospitalityebusiness.com/articles.php

- Tan, C. (2015). The Impact of Hotel Website Quality on Customer Reservation, Master of Science in Hotel Administration, State University of New York

- Toh, R. S., Raven, P., and DeKay, F. (2011). Selling rooms: Hotels vs. third-party websites. Cornell Hospitality Quarterly, 52(2), 181-189.

- Travelclick (2012). Flash Sale Sites Lose Popularity with Hoteliers TravelClick survey shows dissatisfaction with group discount model.

- Travelclick (2013). Transient travlers continue to book more hotel rooms online in the second quarter 2013.

- Trusov, M., Bucklin, R. E., and Pauwels, K. (2009). Effects of word-of-mouth versus traditional marketing: findings from an internet social networking site. Journal of marketing, 73(5), 90-102.

- Tso, A., and Law, R. (2005). An empirical study of online pricing practices for Hong Kong hotels. In Information and communication technologies in tourism 2005 (pp. 328-337). Springer, Vienna.

- Tucker, L. R., and Lewis, C. (1973). A reliability coefficient for maximum likelihood factor analysis. Psychometrika, 38(1), 1-10.

- Varkaris, E., and Neuhofer, B. (2017). The influence of social media on the consumers' hotel decision journey. Journal of Hospitality and Tourism Technology, 8 (1), 66-77.

- Villanueva, J., Yoo, S., and Hanssens, D. M. (2008). The impact of marketinginduced versus word-of-mouth customer acquisition on customer equity growth. Journal of marketing Research, 45(1), 48-59.

- Wang, D., Xiang, Z., Law, R., and Ki, T. P. (2016). Assessing hotel-related smartphone apps using online reviews. Journal of Hospitality Marketing and Management, 25(3), 291-313.

- Wong, J., and Law, R. (2005). Analysing the intention to purchase on hotel websites: a study of travellers to Hong Kong. International Journal of Hospitality Management, 24(3), 311-329. Retrieved from: http://doi.org/10.1016/j.ijhm.2004.08.002

- Wu, J. H., and Wang, S. C. (2005). What drives mobile commerce? An empirical evaluation of the revised technology acceptance model. Information and management, 42(5), 719-729.

- Wu, J. J., and Chang, Y. S. (2005). Towards understanding members' interactivity, trust, and flow in online travel community. Industrial Management and Data Systems, 105, 937-954.

- Yavas, U., and Babakus, E. (2003). What do guests look for in a hotel? A multiattribute approach. Services Marketing Quarterly, 25(2), 1-9.

- Zhao, X. R., Wang, L., Guo, X., and Law, R. (2015). The influence of online reviews to online hotel booking intentions. International Journal of Contemporary Hospitality Management,.27(6), 1343-1364. 


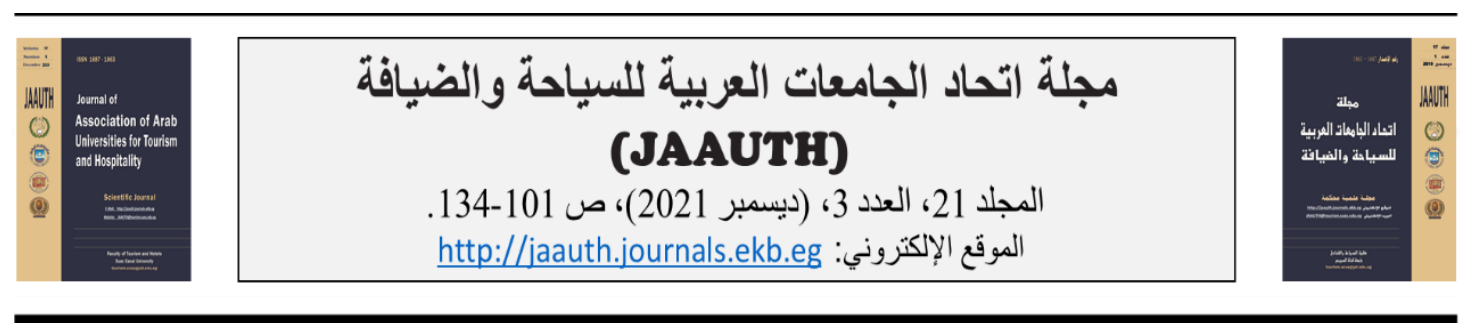

\section{العوامل المؤثرة في نوايا حجز الفنادق من خلال تطبيقات وسطاء السفر عبر الإنترنت فاطمة محمد عبد العال \\ هاني عصام الدبن محمد}

كلية السياحة وإدارة الفنادق، جامعة حلوان

كلية السياحة وإدارة الفنادق، جامعة حلوان

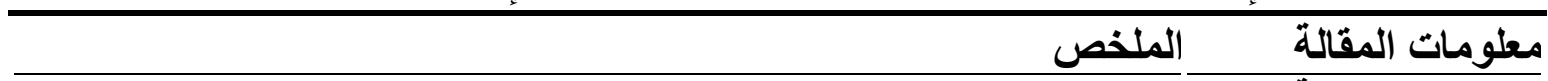

إن النمو الهائل للتكنولوجيا والأجهزة المحمولة في الوقت الحاضر له تأثير كبير على قطاع الضيافة بشكل عام وعلى الفنادق بشكل خاص، وخاصة في حجوزات الفنادق عبر

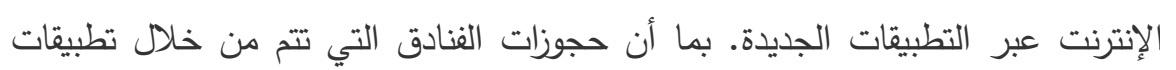
الهاتف المحمول (خاصة من خلال وسطاء السفر مثل Booking و وTrivago) لها دور بارز في قطاع الفنادق. لذلك، تقوم هذه الدراسة بتقييم آراء العملاء فيما يتعلق بالعوامل

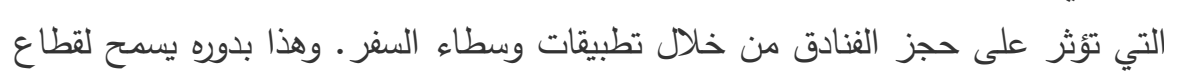
الفنادق بإجراء مزيد من التحسينات لزيادة رضا العملاء أثناء حجز الفنادق من خلال ثقة؛ سهولة الاستخدام المدركة؛ السعر والترويج؛ الخصوصية / الأمان المتصور ؛ المراجعات عبر الإنترنت؛ نية الحجز عبر "طبيقات وسطاء السفر • درست هذه الدراسة بعض العوامل المتعلقة بوسطاء السفر عبر مبرة الإنترنت مثل (الثقة، وسهولة الاستخدام، والسعر والترويج، والخصوصية / الأمان المتصور ، والمراجعات عبر الإنترنت) للتأثير على حجز العملاء الفنادق. وأشار البحث إلى تحليل نتائج الاستبيانات الذي تم استيفاؤه من 208 عميل في فنادق الخمس نجوم في القاهرة. تم الاعتماد على مقاييس من دراسات سابقة تم تطويرها والتحقق منها للعوامل الإنترنت. التي تؤثر على نية الحجز من خلال وسطاء السفر عبر الانترنت لاختبار الفرضيات. تشير النتائج إلى أن سهولة الاستخدام، السعر ، الترويج والخصوصية / الأمان المتصورة

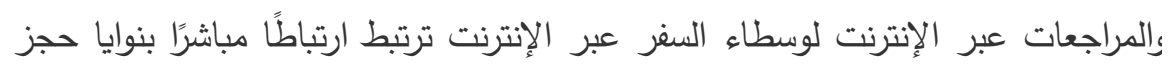

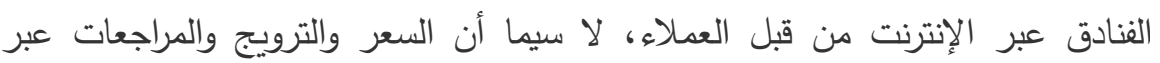
الانترنت تعتبر من العوامل الرئيسية المتعلقة باستخدام وسطاء السفر عبر الانترنت وذلك ولك بسبب شغف العملاء بالحصول على أسعار خاصة لهم عبر تلك التطبيقات وكذلك

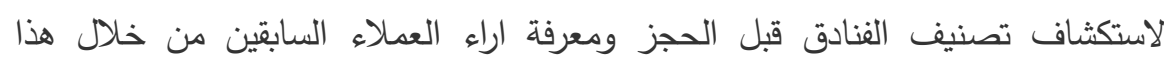
التطبيق لاتخاذ قرار الحجز • وبالتالي، يمكن للفنادق تطوير جودة الخدمة لزيادة تصنيفها من خلال هذه التطبيقات لجذب المزيد من العملاء. 